\title{
ARTICLE \\ One hundred years of rent control in Argentina: much ado about nothing
}

\author{
Alejandro D. Jacobo ${ }^{1,2} \cdot$ Konstantin A. Kholodilin ${ }^{3,4}$ D
}

Received: 7 September 2020 / Accepted: 14 January 2022 / Published online: 8 February 2022

(c) The Author(s) 2022

\begin{abstract}
Following World War I, rent control became a standard policy response to the housing shortage and the resulting rent increases. Typically, economists blame it for creating inefficiencies in the housing market and beyond. We investigate whether rental market regulations (including rent control, protection of tenants from eviction, and housing rationing) had any effects in a middle-income Latin American economy, such as Argentina. To answer this question, we take advantage of a wide range of housing market indicators and restrictive rental regulation indices covering almost one century. Using a standard OLS model and MARS, a nonlinear estimation technique, we find that rental market regulations have exerted a statistically significant negative impact on the growth rates of the real housing rents. However, they were only effective for short periods following both World Wars, when regulations were novel and particularly strong.
\end{abstract}

Keywords Argentina $\cdot$ Housing rents $\cdot$ Rent control $\cdot$ Rental market regulations JEL codes $\mathrm{C} 21 \cdot \mathrm{E} 31 \cdot \mathrm{R} 38$

Hace diez años, señora, que soy aquí su inquilino

y nunca tanto tuvimos estas broncas como ahora.

Usted protesta, señora, con sus gritos imprudentes que entera a toda la gente,

que quiere mi desalojo, porque dice con enojo que soy un tipo indecente... From the milonga "El Inquilino"

Konstantin A. Kholodilin

kkholodilin@diw.de

1 IEF FCE, Universidad Nacional de Córdoba, Blvd. Enrique Barros s/n, 5000 Córdoba, Argentina

2 CICE (CIECS-CONICET), Av. Valparaíso s/n, 5000 Córdoba, Argentina

3 DIW Berlin, Mohrenstraße 58, 10117 Berlin, Germany

4 NRU HSE, Kantemirovskaya ul. 3, Saint Petersburg 194100, Russia 


\section{Introduction}

Following World War I, rent control became a standard policy response to housing shortages and the resulting rent increases. Virtually all countries used such policies throughout twentieth century. A new wave of rent control came in 2020 as a response to the worldwide COVID-19 crisis (Kholodilin, 2020b). In Argentina, housing rents were frozen in March 2020. Typically, economists stigmatize it for creating inefficiencies in the housing market and beyond (Jenkins, 2009). In this study, we investigate whether it had any effects in Argentina, a middle-income Latin American country. To answer this question, we take advantage of a wide range of housing market indicators and restrictive rental regulation indices for Argentina covering more than 100 years. We find that rent control exerted a statistically significant impact on the performance of its housing market.

Sometimes referred to as a configuration of services that satisfy basic human needs, such as shelter, privacy, and identity, among other, housing has always been conceived as a need to be covered (Astorga González, 1995). Many households worldwide strive to be homeowners, since housing is related to the opportunity of having a protective element (against contingencies that affect their income, such as loss of employment or by family extensions). Housing usually means the availability of a capital that reduces uncertainties and it is occasionally a source of income (to rent a room or to set up an economic activity). Some authors even argue that in post-war years - mainly in Western Europe and Latin America and with nuances in both cases - the same state has been the promoter of a "culture of home ownership" by encouraging that citizens reside in their houses as owners rather than tenants (Pareja-Eastaway and Sánchez-Martínez, 2011, p. 53). Still there is a large part of population that lives in rental housing and spends a substantial portion of its income for rent. These people have typically lower incomes than the homeowners.

Since the turn of the twentieth century, the phenomenon of urbanization in Latin America, in general, and Argentina, in particular, is perceived as rapidly increasing, given the high rates of population growth and rise of the industrial activity, which was almost nonexistent before the First World War and notably expanded in, at that time, a purely agricultural economy. Since then, Argentina has experienced a continual housing shortage.

Its constant population growth and the migration of its farmers to urban areas, coupled with an inflow of immigrants to the major cities of Argentina, are all elements leading to ever increasing demand for housing with respect to its supply. This inevitably led to increases in rental prices that inflicted painful financial blows to the tenant households.

Since 1921, the Argentinian government has reacted to these developments by introducing rent control policies, much like governments in many other countries. As a pendulum, phases of stronger regulations have been followed by those of the deregulation. On June 11, 2020, the Chamber of Senators of the Nation sanctioned under the number 27,551 the Ley de Alquileres, which is aimed at strengthening rental market regulations. ${ }^{1}$ Among other things, it provides for capping rent increases by an average growth rate of the consumer price index and the wage index as well as extending the minimum contract duration from two to three years. Thus, Argentina faced a new phase of increasing intensity of rental market regulations. However, this new measure appears to have strong negative byproducts. For instance, in the wake to these regulations $45 \%$ of landlords decided to stop letting

\footnotetext{
1 Ley de alquileres y reforma del CC y CN; http://www.senado.gov.ar/parlamentario/parlamentaria/374144/ downloadPdf.
} 
their rental dwellings and to sell them. This led the Argentina's parliament to discuss the possibility of phasing out the law for 180 days. $^{2}$

While a simple outlook indicates that the whole world is dominated by the homeowners and, on average, in 81 countries from different regions about $70 \%$ households are homeowners, in Latin America homeownership growth rate has reached its peak in the 1990s and 2000, and it has started to decline. Concomitantly, the number of tenants has increased, and Argentina is along this line.

Although Argentina seems to be a country of homeowners, the housing rental market is becoming more and more important, as seen in Fig.1. The share of tenant households used to be very high (62\%) in 1947, then it declined until it reached its historic minimum in 2001 (about $11 \%$ ). Since 2001, tenant occupancy rates have steadily increased, attaining $17 \%$ in 2017. Similar evolution is observable in Buenos Aires, its largest city, where the rate went from $82 \%$ in 1947 to $21 \%$ in 1991 and back above $34 \%$ in 2018 .

According to Blanco et al. (2014), the number of tenants in Latin America has increased due to three reasons. First, the current housing policies based on subsidies are unsustainable from a fiscal perspective, insufficient to satisfy the demand, and inefficient in terms of the land-use patterns. Second, the growth of the cities has increased the scarcity of welllocated urbanized land, which makes housing even less affordable. Third, the demographic changes (decrease in average size of households, rising divorce rates, and growth of the number of single-person households), coupled with a higher labor mobility associated with more flexible and globalized economies, make several households choose not to acquire their own home.

As to Argentina, additional reasons have stopped this trend and induced rental tenure. On the one hand, the increase in the price of houses (whose values are regularly estimated in US dollars) observed in recent decades was higher than the evolution of wages (also measured in US dollars). Indeed, at the beginning of the twenty-first century, real estate market has operated as a storage of value and the real-estate construction boom (channeling the surplus of agricultural income) produced in Buenos Aires, Córdoba, Rosario, and Santa Fe, etc., thus, stimulating house price increases (Carné, 2021).

On the other hand, the restrictions on mortgage credit have also played a role. Few households can meet income requirements from financial institutions in order to qualify for the credit.

In addition, the requirements imposed on the potential tenant by the landlord are often difficult to satisfy. Typically, the tenant must provide two guarantors (homeowners), who would be eager to pay his rent in case he will default. Moreover, the tenant must present his salary receipts that prove that his formal income is high enough. On top of this comes the provision of a safety deposit (refundable at the end of the contract) and the payment of a fee to the real estate agent.

In Argentina, interventions in the housing market use rent control and other restrictive measures were only effective during two short periods, being rather ineffective the rest of the time. For example, during Perón's first presidency, the real estate market was virtually paralyzed. This was a consequence of a 1943 law that froze rents and interrupted evictions. These norms, in force until the fall of Perón in 1955, produced a severe contraction in the supply of dwellings for rent, because the profit expectations of real-state investors abruptly

\footnotetext{
2 Santiago Filipuzzi (25th of November 2021) "Sergio Massa dijo que la ley de alquileres "fracasó” y llamó a discutir un nuevo proyecto en el Congreso" La Nación.
} 
declined. Moreover, when Perón took the reins for his second presidential term, the economic outlook was very poor.

Under the circumstances, where rents were frozen and evictions not permitted, the real amount paid by occupants shrank to almost nothing and the market for houses for rental purposes almost disappeared. In what remained from the formerly large rental market, various means of avoiding the regulations were invented. For example, in order to get a place to stay, tenants agreed with landlords to pay the property taxes in addition to the rent. The fiscal appetite of the different governments also did not contribute to the effectiveness of rent controls. In fact, as landlords must pay income tax on rents received, contracted rents do not reflect reality: tenants pay the sum listed in the contract plus an additional amount through previously agreed promissory notes. Additionally, rental contracts require stamp duties. In almost all cases, the contract is not stamped by the parties in order to avoid this tax or is marked by half of the amount as agreed upon between the landlord and the tenant. The lack of stamp duties payment does not make a contract null. In case of eviction, the only risk that the landlord is bearing is the necessity to pay the stamp duties plus a penalty fee, which turns out to be ridiculously small when inflation is high.

There is an extensive literature on the effects of rent control, as shown in Table 1. Most studies address the US experience: nine out of 14 listed in the table. The rest focus on European countries, mostly Scandinavian (Denmark and Sweden). The majority of studies (nine) work with microdata, typically at the private household level. The studies concentrate on topics like residential mobility, misallocation of housing, rents, and homelessness. Few consider the effects on residential construction (Sims, 2007). The statistical methodology covers a wide range of techniques varying from simple cross-sectional regressions through panel data models and nonlinear models such as proportional hazard model, duration model, and logit. To our knowledge, there are no studies using econometric tools to analyze the effects of governmental regulations on the Argentinian housing market.

The contribution of the paper is threefold. First, it concentrates on the impact of rent control in a middle-income Latin American country. Second, this is the first assessment of rental regulations for Argentina and the overall region. Third, it uses a novel database with long-term time series of the Argentinian housing market.

This paper is organized as follows. Section 2 describes the data, their sources and transformations. Section 3 presents the estimation methodology. Section 4 reports and discusses the estimation results. Finally, Sect.5 concludes.

\section{Data}

In this section, the sources, transformations and characteristics of data are described. The list of data with their sources are reported in Table 2. Below, we describe the data used in this study in more detail.

It is difficult to obtain overlapping time series for the variables under different base periods in Latin American countries over the long-run and Argentina is not an exception. It is typical that, once the base period is changed, the old time series (based on the previous base period) are discontinued and the new ones are not extended backward for a significant number of years. Frequently, a change in the base period usually reflects improvements in statistical procedures that began in Argentina during the 1960s when its statistical system started developing. This makes unclear whether the observed differences across base periods effectively reflect changes in the series or merely shows the peculiarities of statistical 
procedures. Regardless, we carefully describe the variables as shown in Table 2 and adopt the "second-best methodology" consisting in the simple "chaining" of the series as the only alternative available.

\subsection{Dependent variable}

As our dependent variable, we take the average monthly rent index of a room in the City of Buenos Aires for the period 1914-1934 published by the Departamento del Trabajo of the Ministerio del Interior through its statistics division. From 1934 to 1961, the numbers also come from a contemporary index considering the consumption of a $4 \times 4.5$ meters room by an unskilled worker's family type (parents and two children under 14 years old) living in the City of Buenos Aires. We take the data from publications of the former Dirección Nacional de Estadística y Censos (DNEC, hereafter). This office also provides information for the 1961-1976 period and the variable turns out to be the rent of a house (excluding electricity) according to a survey on the living conditions of a working family ("familia obrera") carried out in the capital of Argentina.

According to the official statistics that we follow, rent for 1977-1988 comes from the consumer price index and include housing expenses. The set of goods and services selected in the expenses are sanitary repairs, tiles, cement, bricks, wood, and paint. This group excludes other things (gas, the cost to refill a balloon of gas, kerosene, charcoal and electricity). The index considers the capital of Argentina. However, from March 1977 the index includes the capital of the country and 19 suburban communities. The information for the index comes from the Encuesta Permanente de Hogares (Permanent Household Survey) and the data are elaborated and published by the Instituto Nacional de Estadística y Censos (INDEC is the Spanish acronym for the National Institute for Statistic and Censuses). As for 1988-1999, the index measures the evolution of the monthly effectively rent paid by households, with expenses considered separately.

For 1999-2013, the survey of the rental prices is monthly and based on the division of the geographical area into work zones composed of the City of Buenos Aires and the Greater Buenos Aires.

Finally, for 2014-2017, data come from the Dirección General de Estadística y Censos of the City of Buenos Aires. The IPCBA (this is a Spanish acronym for Consumer Price Index of the City of Buenos Aires) contains the rent variable.

The time series of monthly rent coming from different sources are linked to obtain a series covering the period 1914-2017, which is the first attempt of this sort for Argentina. The individual rental price indices with different basis years and coverage are shown in Figure 2. This nominal rent is deflated using the consumer price index. The growth rates of the resulting time series are displayed in Figure 3.

In order to account for the methodological differences across these seven periods, in all regressions below, six dummies are introduced, for 1914-1934, 1935-1960, 1961-1976, 1977-1988, 1989-1998, and 1999-2013, denoted as D_meth1, ..,D_meth6.

\subsection{Control variables}

Interest rate. From 1914 to 2008, the series represents the interest rate for 30-days loans in domestic currency (peso) to first-line companies (prime rate). From 2009 on, it is the 30 -days discount rate to promissory notes. Ferreres et al. (2005) provides information for 
the 1910-2004 period. The series is updated with information from the web page of the Banco Central de la República Argentina.

Gross Domestic Product As usual, the series is the sum of good and services produced by the Argentine economy during a year. Ferreres et al. (2005) covers 1910-2004, while the national accounts compiled from INDEC allow us to properly update the series.

Consumer Price Index The series is from Ferreres et al. (2005), who presents values up to 2004. However, to continue the series, we have to consider the government's intervention in the Argentine Statistics Bureau (INDEC) from 2007 through 2015. During these years, the government started reporting official statistics that were systematically below the unofficial ones. We follow Cavallo and Bertolotto (2016) to update the annual series.

Population This variable indicates the projected population in thousands of persons. From 1910 to 2004 the data come from Ferreres et al. (2005), while the series up to 2017 are from Dirección General de Estadísticas y Censos de la Ciudad de Buenos Aires.

Building permits This variable broadly corresponds to the number of building permits, i.e., the administrative procedures through which the authorization for the construction of a building is requested. Each building permit generally corresponds to a work, so this variable largely reflects the number of buildings authorized. The source is the Revista Económica from the Banco de la Nación Argentina for the 1926-1934 period. A special request by the authors was made to the Dirección General de Estadística y Censos of the City of Buenos Aires for 1934-1943 data. From 1944 to now, data proceed from the building series of the national statistical office of Argentina through its different names (Dirección, Nacional del Servicio Estadístico, Dirección Nacional de Investigación Estadística y Censos, Dirección Nacional de Estadística y Censos, and INDEC). Unfortunately, to our knowledge, information about building permits is not available prior to 1926.

Demographics We use two demographic variables: the population growth and the growth of the number of marriages. This represents the demand side of the housing market. A large population represents a higher demand for the living space. Likewise, the number of marriages proxies the formation of the new households, each of which, at least in theory, requires a separate dwelling. It is expected that these variables should exert a positive impact on the housing rents.

Political orientation of the government The researchers both in political science and economics have used the left-right spectrum to explain political decision making, starting with Downs (1957). It can be expected that the leftist governments are more inclined to expand social policies, including rent control. The proxy used here is the orientation of the political party of the head of the government belongs. This variable is constructed by Brambor et al. (2017). It takes three values: -1 for left, 0 for center, and 1 for right. Thus, the expected sign of the regressor is negative.

The evolution of control variables between 1910 and 2017 is shown in Fig.3. The real rent growth is quite volatile with several large peaks between 1960 and 1980. The real interest also varies wildly between - 70 and 20. It is very negative between 1960 and 1990 due to a large hyperinflation in that period. The population growth shows a secular decline with several cycles. Between 1910 and 2016, it dropped from 3.5 to $1 \%$ a year. The two indicators of the real GDP (Maddison Project Database and the indicator compiled by authors from different sources) have very similar dynamics, the compiled indicator showing slightly higher growth rates than that from the MPD. The building permits growth is also quite volatile, with the variation increasing toward the end of the sample. It is also a variable that starts in 1927, much later than all other time series. Finally, the left-right government index of Brambor et al. (2017) shows the fluctuations in the political orientation of the heads of government in Argentina. Most governments appear to belong to the right 
wing of the political spectrum. Only three times the leftists managed to gain control over the government: 1943-1955, 1966, and 2002-2012.

\subsection{Regulation indices}

This study focuses on the effects of governmental policies. Therefore, we need measures of their intensity. For this purpose, we use the restrictive rental market regulations indices elaborated by Kholodilin (2020b) and Weber (2017). These indices cover three types of regulations: rent control, tenure security, and housing rationing. All three indices vary between 0 and 1: the higher the index, the more intense the regulation. The indices are constructed for Argentina based on a thorough analysis of the corresponding legal acts. Table 4 summarizes all relevant laws underlying the rental market regulation indices utilized in this study. Figure 4 depicts the evolution of the three indices between 1910 and 2017, with shaded areas denoting both World Wars. For comparison purposes, it also shows the evolution of the indices for Latin America and the world.

Rent control index measures the intensity of restrictions imposed on the level of rent and its rate of increase. The index is computed as a simple average of six binary variables: 1) rent level control, if rents are set by some governmental body, court, arbitration council or similar and not by a free negotiation between tenants and landlords; 2) nominal rent freeze, if rent increases are prohibited; 3) real rent freeze, if rent increases are allowed but cannot exceed the growth of a cost of living index; 4) intertenancy decontrol, if a tenant change implies a deregulation of the formerly regulated dwelling; 5) other specific rent decontrol, if rent control is not applicable to certain types of dwellings (e.g., newly built or luxury ones); and 6) specific rent recontrol, if stricter rent control is applied to types specific households (e.g., low-income or having military as their member), areas (e.g., communities with tight housing market), or types of landlords (e.g., big ones). These binary indices take the value 1 , if in particular year a corresponding restriction exists or exception is absent. Using the simple average implies equal weights of all the binary indices and, thus, their equal impact on the resulting composite index. Using different weights would be arbitrary, since it would be difficult to justify why certain binary indices should obtain higher weights. Moreover, even if some objective weighting rule could be found, it would be difficult to implement it due to the lack of data, when it is done on an international scale. In addition, the economists distinguish between first- and second-generation rent controls (Arnott, 1995). The first generation implies a rent freeze, when rents are fixed at some level. For instances, in Argentina rents were frozen three times: 1921-1924, 1943-1956, and 1965-1970, at the January 1, 1920 level, at the December 31, 1942 level, and at the previous contract level, respectively. Under the second-generation rent control, the rent level, as a rule, is not frozen; instead, the restrictions are imposed on the growth rate of rent, which is typically anchored to some measure reflecting the cost of living. In this way, lawmakers guarantee that the real rental revenues of the landlords are not eroded by inflation. In Argentina, in 1970, rent increases were capped by the rate of increase of the official index of living costs (índice de costo de vida). However, between 1987 and 2014, the rents were nominally frozen, for the government did not allow rent to be indexed by inflation in order to avoid an inflationary spiral. In terms of the index construction, the first-generation rent control implies that both rent control level and nominal and real rent freezes exist, while under the second-generation rent control, only real rent freeze exists.

The tenure security index reflects the degree of protection that tenants have from evictions by landlords. The main instruments of protection are 1) eviction protection during 
term or period; 2) eviction protection at the end of term or period; 3) imposition of a minimum duration of rental contracts; and 4) prohibition of short-term (less than one year) tenancies. Between 1921 and 1949, the first two tools were applied in Argentina: contracts could be automatically prolonged by tenants and landlords could only evict them, if they had justifiable reasons to do so. These reasons included: 1) non-payment of rent; 2) abusive use of the rented premises; 3) tenants initiating scandals (escándalo); 4) the owner needs the dwelling for himself and his family; or 5) the owner plans to rebuild the house, having low housing capacity, in order to create more dwellings, etc. In 1949-1957, the restriction on the minimum duration of rental contracts was added. In 1957, this requirement was abandoned. Finally, from 1976 on, the automatic prolongation of existing rental contracts was no longer provided to the tenants. However, during the term of those contracts, the tenants are still protected from eviction.

The housing rationing index measures the intensity of redistribution of the existing housing stock. In Argentina, between 1949 and 1965, three such policies were applied: 1) obligatory registration of vacant dwellings by landlords and subletting tenants within 15 days; 2) landlords are required to let their dwellings within 30 days; and 3) in the Federal Capital and National Territories, the authorities can requisition vacant dwellings.

The rental housing market regulation indices have their weaknesses, being a result of a tradeoff between the feasibility and the complexity of the real world. First, they are based on the formal laws and do not take into account their enforceability related to the effectiveness of the legal system and the degree of the legal literacy of the society. Second, these indices account for a limited number of relevant characteristics, skipping some other features. For example, they do not include the regulations concerning security deposits or subletting. Third, rental regulations typically apply to a specific segment of the housing market. If the size of this segments changes over time (for example, the rental market squeezes), the application sphere of regulations changes, too. However, due to the data limitations it is not always possible to take this into account.

All variables are tested for stationarity. The results of the augmented Dickey-Fuller unitroot tests are reported in Table 5. For the real interest rate (RIRate), the null hypothesis of unit-root (presence of random walk) can, in most cases, be rejected at conventional significance levels. Other variables become stationary after taking first differences. Only the growth rate of population (DLPop) appears to be non-stationary reflecting a secular decline in the speed of expansion of Argentina's population. In addition, we tested our series for cointegration using the Engle-Granger test (Engle and Granger, 1987). The alternative hypothesis of the existence of a cointegrating relationship between the levels of variables could not be confirmed at $10 \%$ of significance. Therefore, we are going to use the growth rates in our regressions.

\section{Econometric methodology}

In order to investigate the potential impacts of rental regulations on the real growth rates of housing rents, we use different estimation approaches.

First, we take advantage of a simple ordinary least squares (OLS) model:

$$
y_{t}=\alpha+\rho y_{t-1}+\sum_{k=1}^{K} \beta_{k} x_{k, t-1}^{C}+\sum_{l=1}^{L} \gamma_{l} x_{l, t-1}^{R}+\varepsilon_{t}
$$


where $y_{t}$ is the growth rate of real rent in period $t ; x_{k t}^{C}$ is a $k$-th control variable; $x_{l t}^{R}$ is an $l$-th regulation index (our focus variable); $\varepsilon_{t}$ is the disturbance term; and $\alpha, \beta$ 's, $\gamma$ 's, and $\rho$ are parameters to be estimated. Note that explanatory indices are taken with a lag in order to avoid possible endogeneity. Here, we use a dynamic model in order to account for the possibility of persistent rent growth. The advantages of the linear model are its simplicity and easy interpretation. It is also the most widely used model in the literature. A big disadvantage is that linear models ignore possible nonlinear effects and sometimes do not find any effects at all, if the relationship between dependent and explanatory variables changes over time. This can be especially true, when the policy effects are investigated, since both policies and society undergo changes. Moreover, the society can adapt to the policies and, thus, render them less effective, as the famous Lucas critique suggests (Lucas, 1983).

Second, we employ a multivariate adaptive regression splines (MARS) algorithm. This is a nonparametric piecewise regression technique that was introduced by Friedman (1991). It is especially useful for identifying nonlinearities in regression models. These are modeled using potentially different slopes for each predictor. Thus, unlike the linear regression, MARS does not assume that coefficients are stable across the entire range of each variable and instead uses splines in order to fit piecewise linear continuous functions. This is very useful when considering long-run economic processes, where policy responses may be subject to structural breaks. The main advantages of MARS compared to other nonlinear models (e.g., polynomial models) are the simplicity of the resulting econometric model, its interpretability, and automatic model selection.

Here, we use matrix notation in order to formulate MARS. The dependent variable $Y=\left(y_{1}, y_{2} \ldots, y_{T}\right)^{\prime}$ is regressed upon a set of potential explanatory variables $X=\left(X_{1}, X_{2}, \ldots, X_{K}\right)$ with $X_{k}=\left(x_{k 1}, x_{k 2}, \ldots, x_{k T}\right)^{\prime}$, where $k=1,2, \ldots, K$ is the number of regressors and $t=1,2, \ldots, T$ is the time index. The MARS uses the so-called basic functions $(\mathrm{BF})$ of the form $(x-c)_{+}=\max \{0, x-c\}$ and $(c-x)_{+}=\max \{0, c-x\}$, where the subscript "+" means that the function takes only a positive value or zero in case of negative difference. In other words, the threshold $c$ splits the corresponding explanatory variable in two subsets: the values above and below $c$. Thus, two new variables emerge: 1) values exceeding $c$ or zeros and 2) values below $c$ or zeros. The sum of these two variables is equal to the original explanatory variable. When included into regression instead of the original variable, this pair of newly constructed variables allows modeling the impact of the explanatory variable in a nonlinear way - as two linear pieces with different slopes. Such pairs of linear functions are called "hinge functions" and the constant $c$ denotes a knot, where the slope changes. The collection of all possible BFs, $\mathcal{C}$, is used to construct the following model:

$$
\mathcal{C}=\left\{(x-c)_{+},(c-x)_{+}\right\} \text {with } c \in\left\{x_{k 1}, x_{k 2}, \ldots, x_{k T}\right\} \text { and } k=1,2, \ldots, K
$$

Each function is piecewise linear with a knot $c$ at every $x_{k t}$, and, in case if all input values are distinct, there are $T K$ hinge functions, or equivalently $2 T K$ basic functions. The modelbuilding strategy is similar to a classical forward stepwise regression using as inputs the functions from the set $\mathcal{C}$ and their products. The complete MARS model is formulated as:

$$
Y=\beta_{0}+\sum_{k=1}^{K} \beta_{k} h_{k}(X)+\epsilon
$$

where $h_{k}(X)$ is either a $\mathrm{BF}$; or a product of two or more such functions, if interactions between variables are permitted; or the original explanatory variable, if it exerts a linear 
impact on the dependent variable; and $\epsilon$ is an error term. Here, however, we do not consider interactions. The coefficients $\beta_{k}$ are estimated by minimizing the sum of squared (residual) errors (SSE), similar to a standard linear regression model.

The model-training process iteratively selects and adds some hinge functions to the model (or the original explanatory variable). During each step of the training process, MARS selects new terms that minimize the SSE using OLS. In this forward pass, the MARS algorithm starts with a single model including only the intercept term $\beta_{0}$. At each subsequent step, a pair of hinge functions and an original explanatory variable are selected and added to the model. The forward pass continues until it meets one of many conditions such as: 1) the maximum number of model terms (chosen by the user) before pruning is reached; or 2) when adding a term $R^{2}$ changes by less than a threshold value selected by the user (e.g., 0.001). In general, at the end of this process, we have a large model in the form described by equation (2). The MARS model obtained in this forward pass is adaptive and can exhibit a great degree of flexibility that can ultimately result in overfitting, if no measures are taken to counteract it. To solve the overfitting problem and build a model with better generalization ability, a pruning procedure must be applied. The pruning implies that a one-at-a-time backward deletion procedure is applied during which basis functions with the least contribution to the model are repeatedly eliminated.

\section{Results}

The OLS regression estimation results are shown in Table 6. Columns (1) and (2) report the results of two models estimated using OLS. Both models include a subset of control variables that are typically included in the regressions explaining the dynamics of housing rents regardless of whether their coefficients are statistically significant or not. In addition, model (1) contains the Rental Market Regulation Index (RMRI) and housing rationing index, while model (2) contains rent laws, tenure security, and housing rationing indices. Given that RMRI is a simple average of rent laws and tenure security indices, we can only use it together with the housing rationing index in order to avoid multicollinearity. Both the studentized Breusch-Pagan test and non-constant variance score test have very low $p$-values pointing out to the existence of heteroskedasticity. ${ }^{3}$ The Durbin-Watson test could not reject the null of no autocorrelation, ${ }^{4}$ which is not a big surprise, given that we use dynamic models. Finally, the Shapiro-Wilk test of normality rejects the null hypothesis of the normal distribution of the regression residuals. ${ }^{5}$ Therefore, we employ bootstrap approach to calculate consistent standard errors. The bootstrapping is done using 300 replications. ${ }^{6}$ The autoregressive term is only significant in model (2). However, it has a negative sign, indicating rather erratic fluctuations of real rent growth rates instead of persistent dynamics. The only control variable that is statistically significant is the real interest rate. None of the regulation indices are statistically significant. This implies that rental housing market regulations have not exerted any linear effect on rents in Argentina. However, it is possible that due to the differences in the rent control regimes between different periods, there might be effects in some periods and opposite or no effects in other periods, cancelling each other

\footnotetext{
3 These tests are carried out using the $\mathbf{R}$ packages sandwich and car, respectively.

4 The test is conducted using the $\mathbf{R}$ package lmtest.

5 The normality test is carried out using the $\mathbf{R}$ package shapiro.test.

6 These are estimated using the lm.boot function of the $\mathbf{R}$ package simpleboot.
} 
over the whole period. In order to verify this possibility, we take advantage of a nonlinear model.

Columns (3) and (4) report the same two models estimated using MARS. The nonlinearity is only allowed for regulation indices. The automatic selection algorithm dropped autoregressive term from both nonlinear models. The models always include the real interest rate, which appears to exert a statistically significant negative impact on the growth of real rents. In model (3), in addition, the Rental Market Regulation Index is contained. It has a negative effect on real rents, when it exceeds 0.542 and no effect below this threshold, see Figure 5. Such regulation intensity is only achieved during two episodes: 1923-1925 and 1945-1957. This is the aftermath of both World Wars.

The first period is consistent with the introduction of rent control; an innovation that probably tended to act as a surprise for the economy at that time and consequently exercised its effects. The second period coincides with the presidency of Perón when Argentina experienced a turbulent subordination of the economy to politics (a "hyper-politization of economic life", in terms of (Gerchunoff and Díaz Alejandro, 1989, p.59). This subordinate position was one of the reasons for the economic enlargement of the public sector and the upsurge of controls, which clearly included rents. The aim and priority of the Perón's government were to rapidly modify income distribution to create an economic order capable of preserving the distributive model pursued. Thus, rental regulations seem to be effective only when they are a novelty or a very strong policy, as they were during these periods.

The results presented here are robust to different specifications. First, the linear models reported in Table 7 use different lags of the control variables and regulation indices: between 2 and 4 years. The idea is that the market participants do not react immediately to the policy changes, but rather with a lag of several years. Moreover, these models include additional variables with respect to our basic model, such as the growth of consumer prices and left-right index. None of these additional variables turns out to be significant. Likewise, the regulation indices remain mostly statistically insignificant, except for model in column (4) that includes the third lags pointing to a possible transitory reaction three years after the regulation was enacted.

Second, Table 8 reports estimation results of linear models including some alternative proxies. The growth rate of per-capita real GDP is approximated alternately by the estimate of the Maddison Project Database and by the estimate that the authors compiled from various national sources. Moreover, instead of the population growth we use the growth of marriages. However, again, neither these variables nor regulation indices are statistically significant.

Third, we estimated the model including regulation indices and and control variables, such as real interest rate, population growth, real GDP growth, building permits growth, as well as methodological-differences dummies using the 40-year rolling dummies. Our first subsample encompasses the period from 1929 to 1968, the second subsample covers 1930-1969, and so on. For each such subsample, both models (1) with RMRI and housing rationing; and 2) with rent laws, tenure security, and housing rationing) are estimated and the coeffcients at regulation indices are stored. At the end, we obtain a time series for each coefficient estimate together with its $95 \%$ confidence interval; see Fig.6. It can be seen that the coefficient of some regulation indices changed dramatically between the first (1929-1968) and the last subsample (1978-2017). For example, the coefficient of RMRI increased from -0.33 to 2.36 . It was statistically significant at the very beginning and then als at the end of the sample. The tenure security index became positive and statistically significant from the 1980s. The housing rationing index declined strongly across the time and became negative and statistically significant in the last two decades of the sample. This 
confirms our hypothesis about the nonlinear effects of rental housing market regulations and explains why the linear model estimated over the whole sample produces statistically insignificant results.

\section{Conclusions}

As most Latin American economies, since the turn of the twentiieth century Argentina has experienced a constant housing shortage. Its continuous population growth and the migration of its farmers to urban areas, together with an inflow of immigrants to the major cities, are all elements leading to ever increasing demand for housing with respect to its supply. The government has reacted to these developments by introducing rent control policies.

In this study, we analyze the effects of rental market regulations in Argentina on the growth of real housing rent. We use a novel database with long-term time series of the Argentinian housing market and take advantage of a wide range of indicators as well as restrictive rental regulation indices for Argentina covering more than 100 years.

We find that these regulations did exert a statistically significant impact on rent dynamics. They appear to dampen real rent increases. However, these effects are observed during two short periods following both World Wars: 1923-1925 and 1945-1957. This means that rental market regulations are effective when both rent control and tenure security are novel or very strong. However, we do not consider potential effects of rent control on other aspects of the housing market, such as residential construction, quality of housing, and homeownership rate. ${ }^{7}$ These effects can counteract the policy-driven declines in real rents making such interventions far from desirable as a tool of rendering the housing affordable.

Hence, the policy recommendation for the governments of middle-income Latin American countries would be to not rely on rent controls and too strong tenure security, since when they are strong, they generate various negative byproducts, while, when they are weak, they hardly slow down rent increases.

\section{Appendix}

See Tables 1, 2, 3, 4, 5, 6, 7 and 8 .

Figures 1, 2, 3, 4, 5 and 6 .

\footnotetext{
${ }_{7}$ As seen in our literature review in Table 1, rent control can lead to all sorts of undesirable effects. In addition, Kholodilin and Kohl (2021) show that rental regulations lead to higher homeownership rates in the long run, thus destroying the rental housing market.
} 


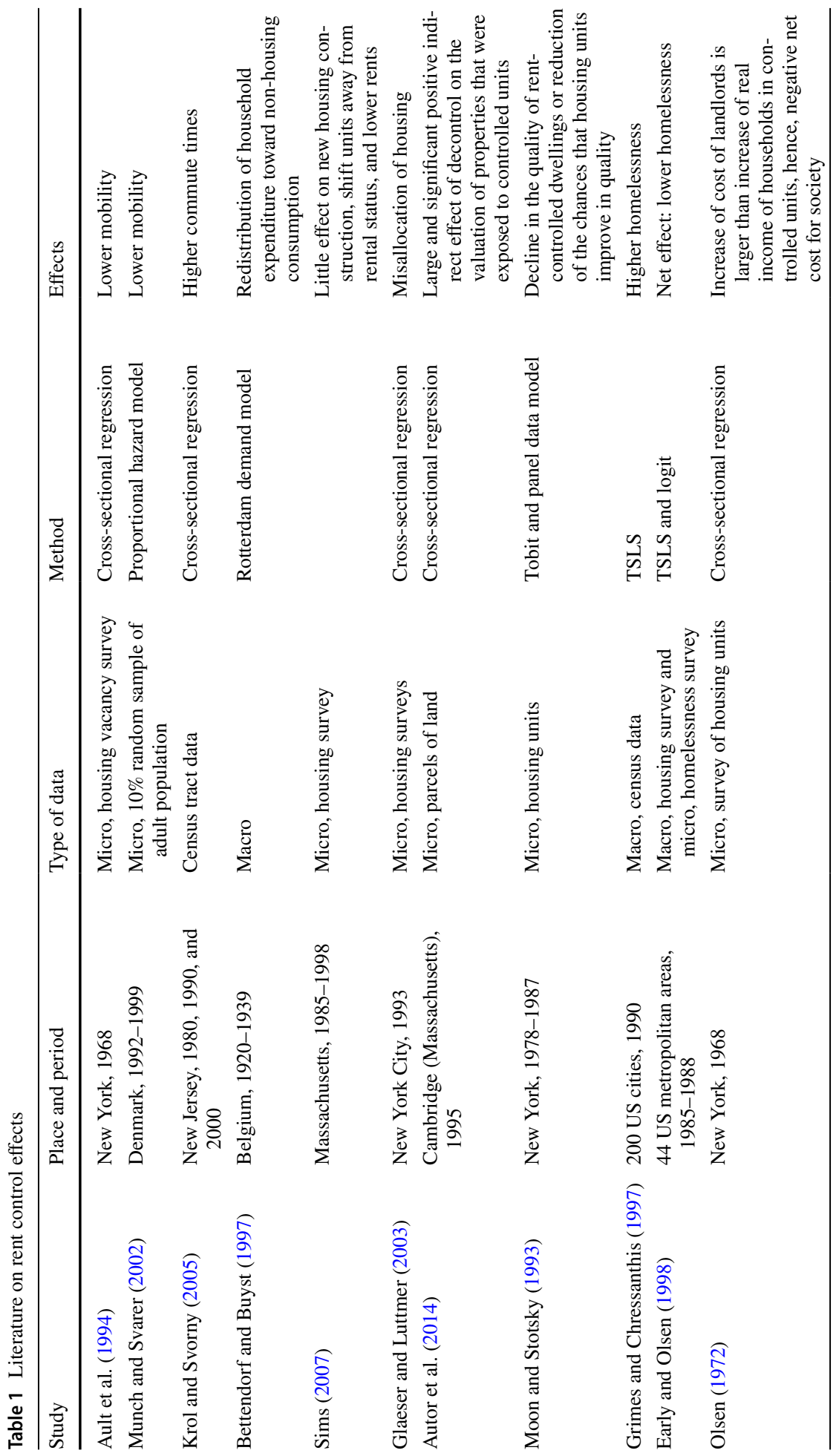




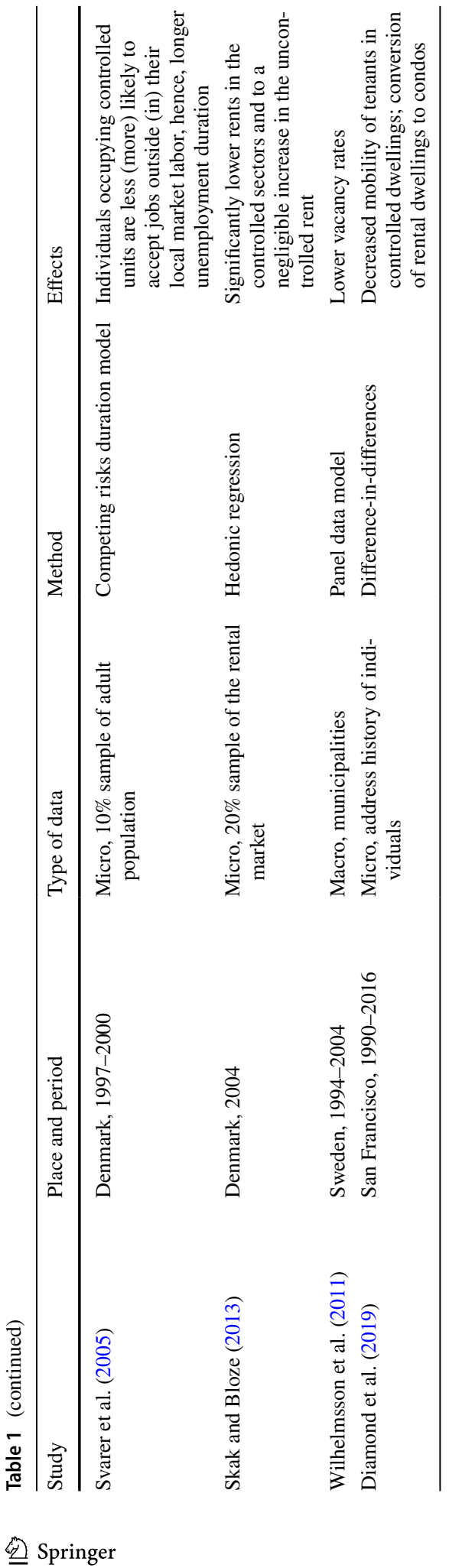




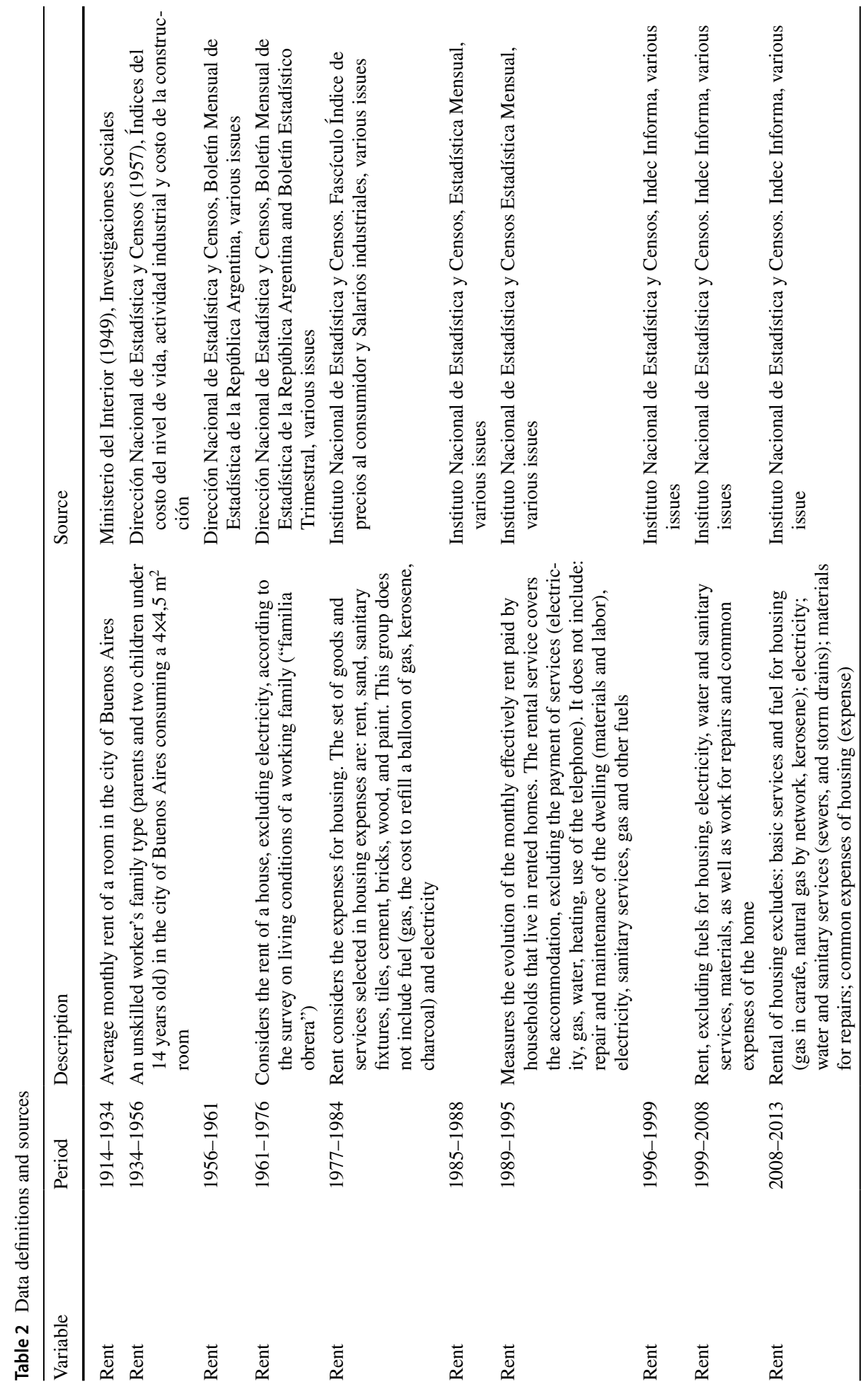




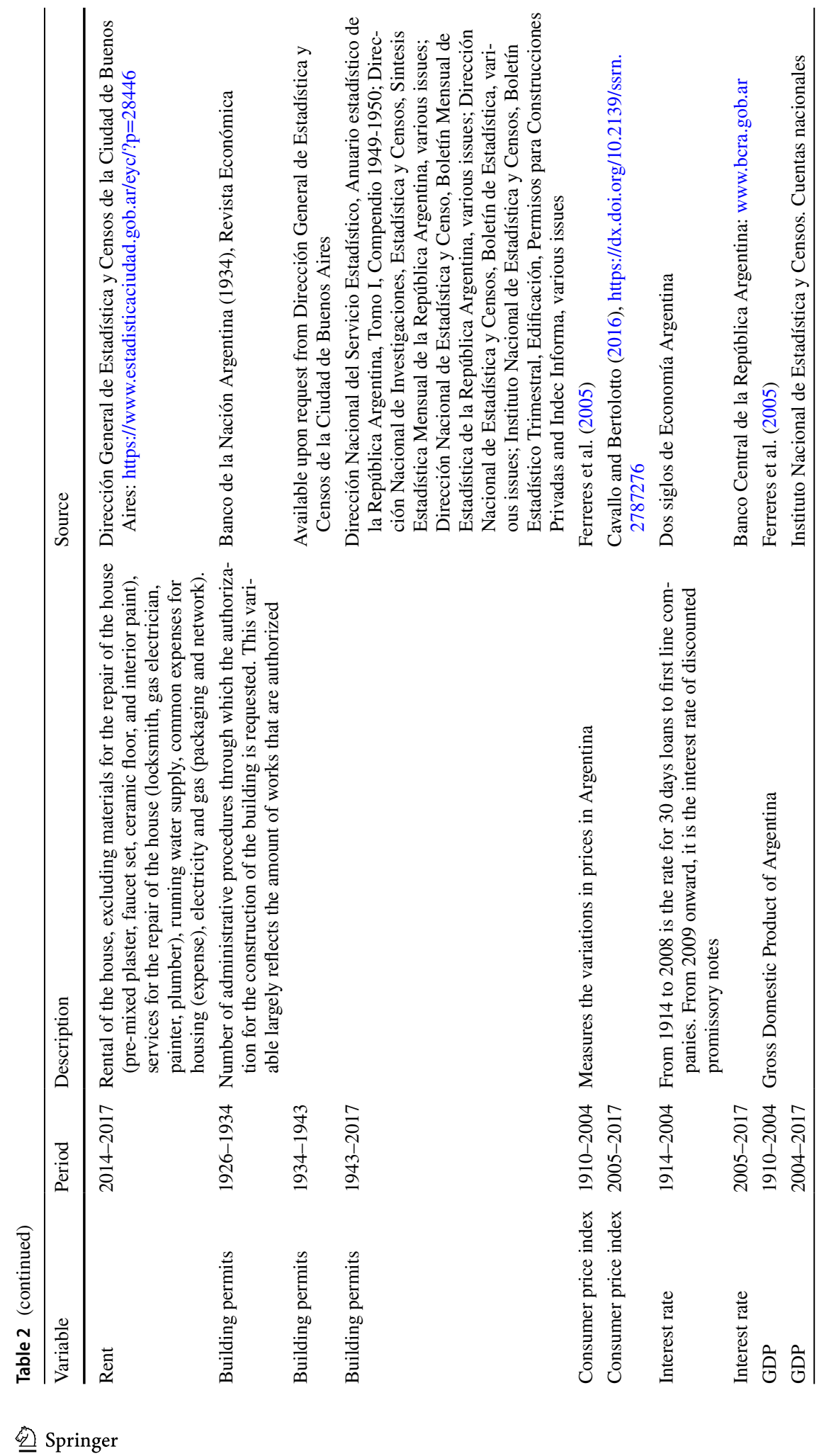




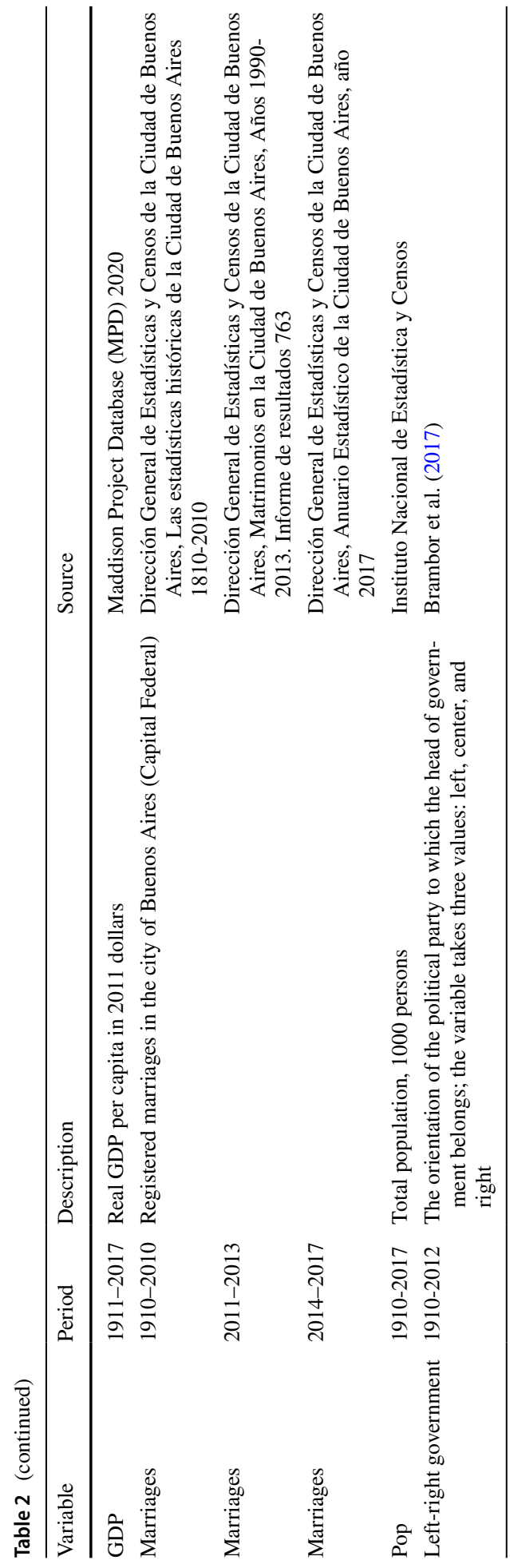




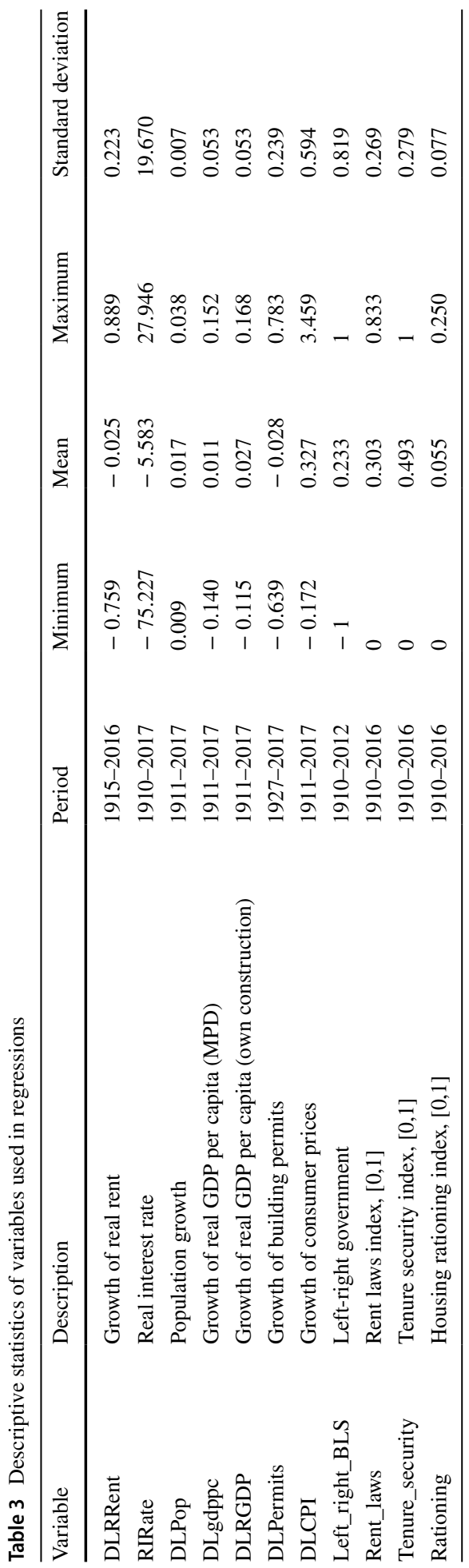




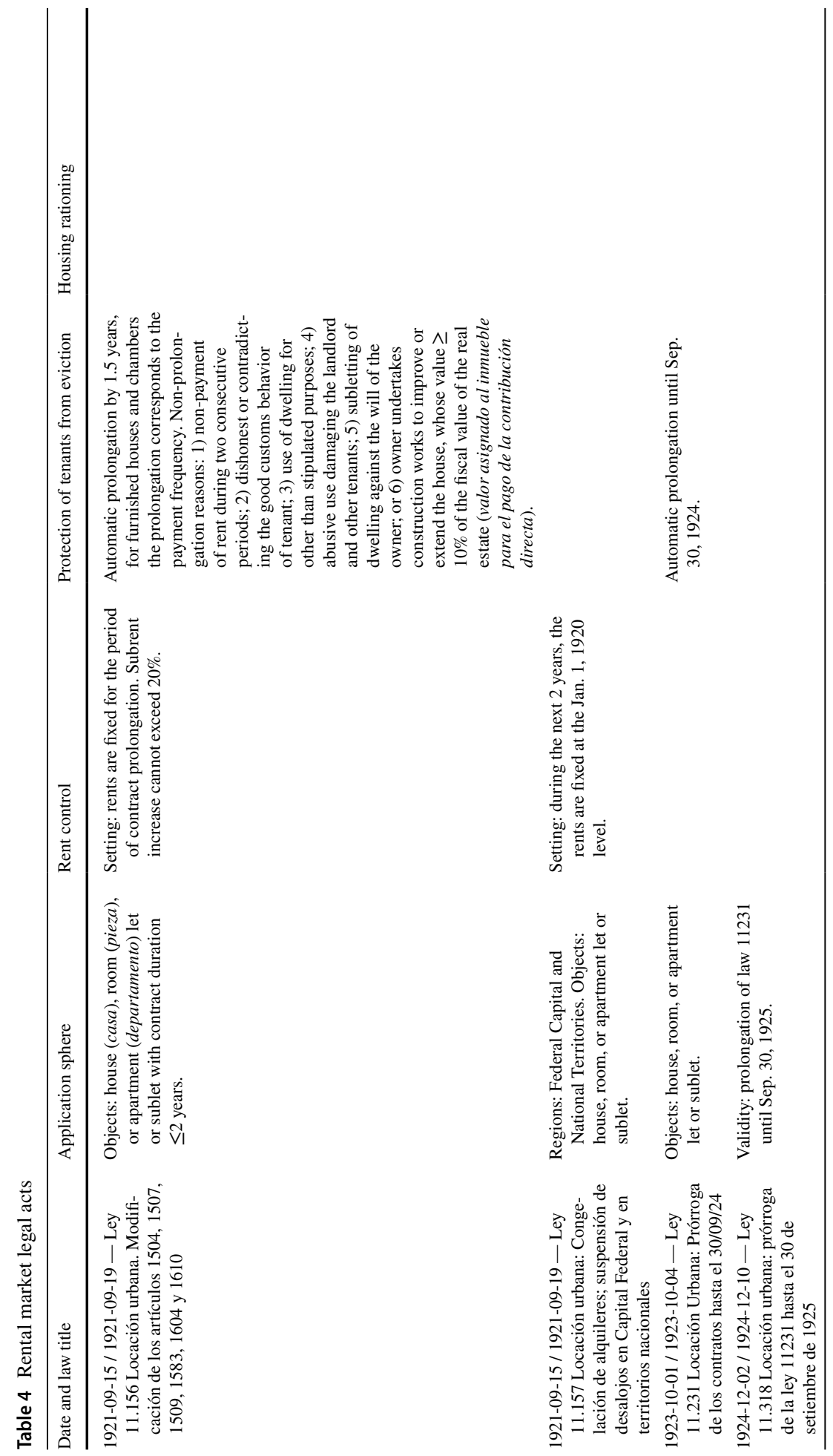




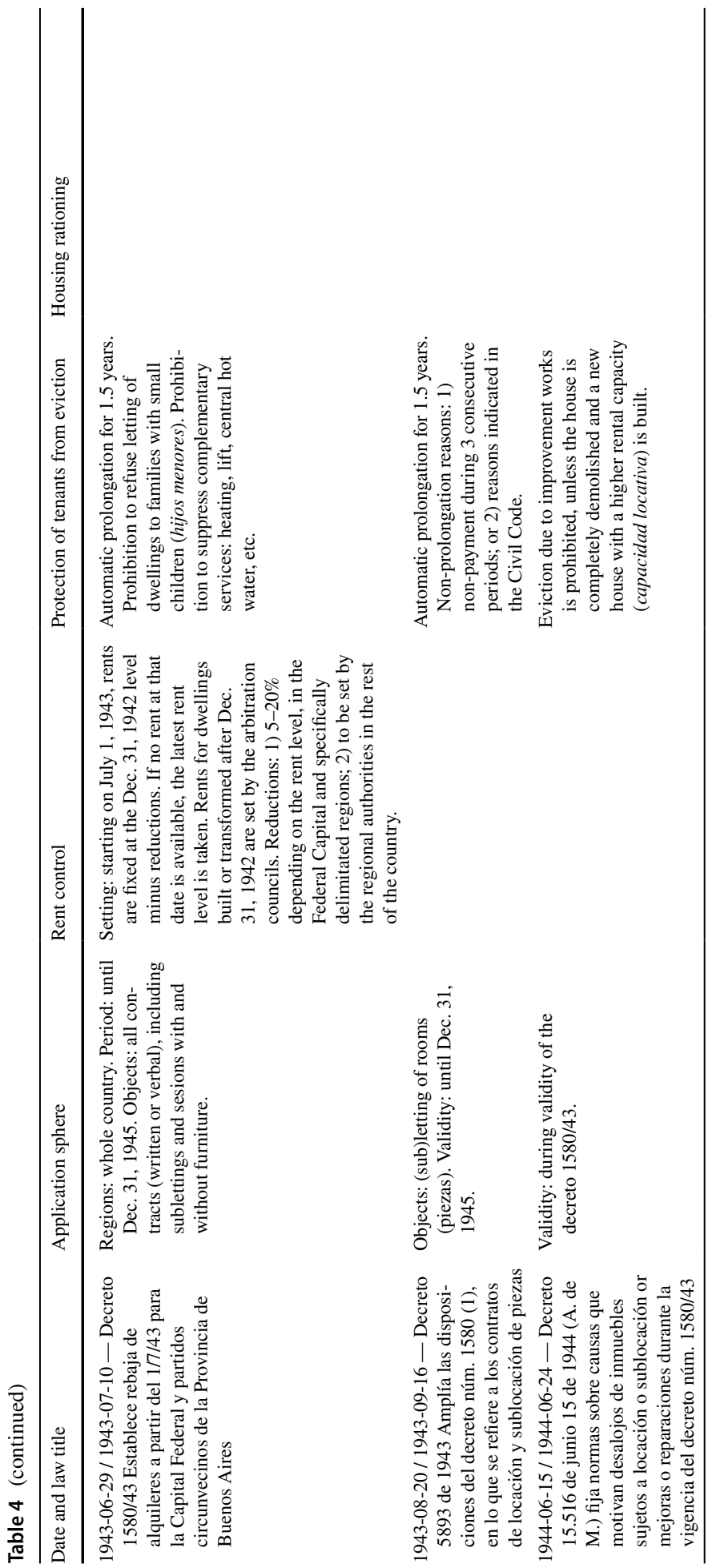




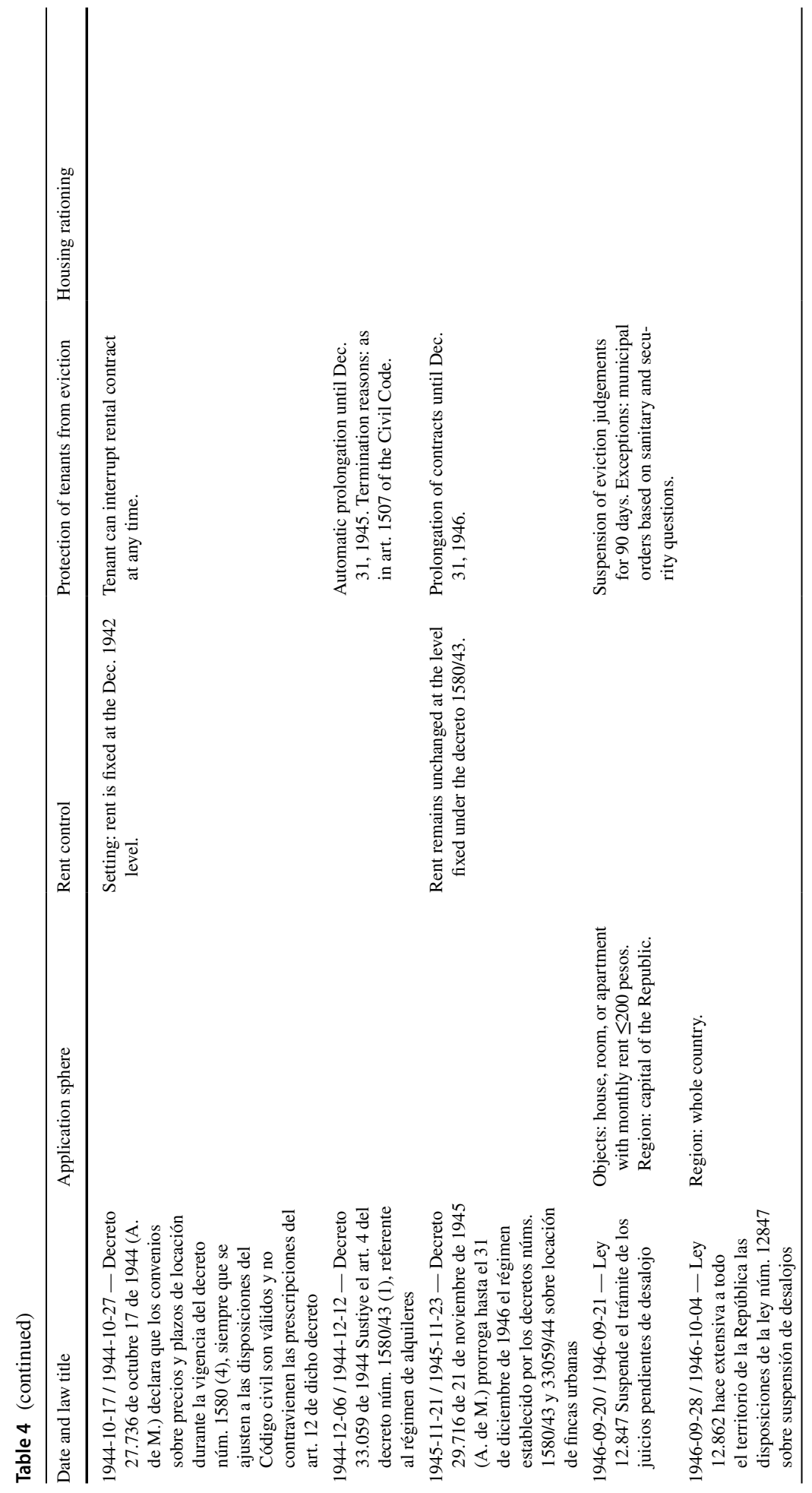




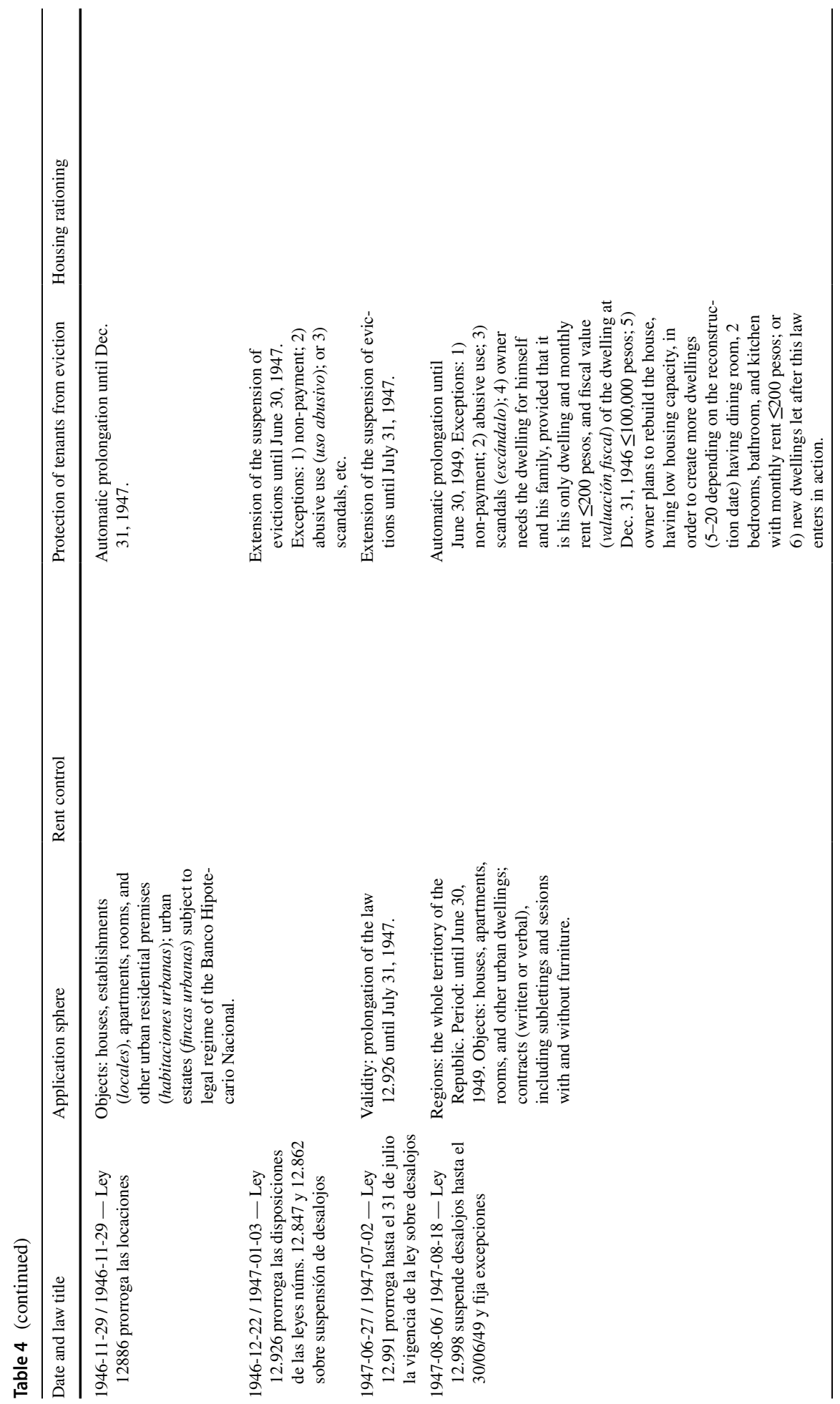




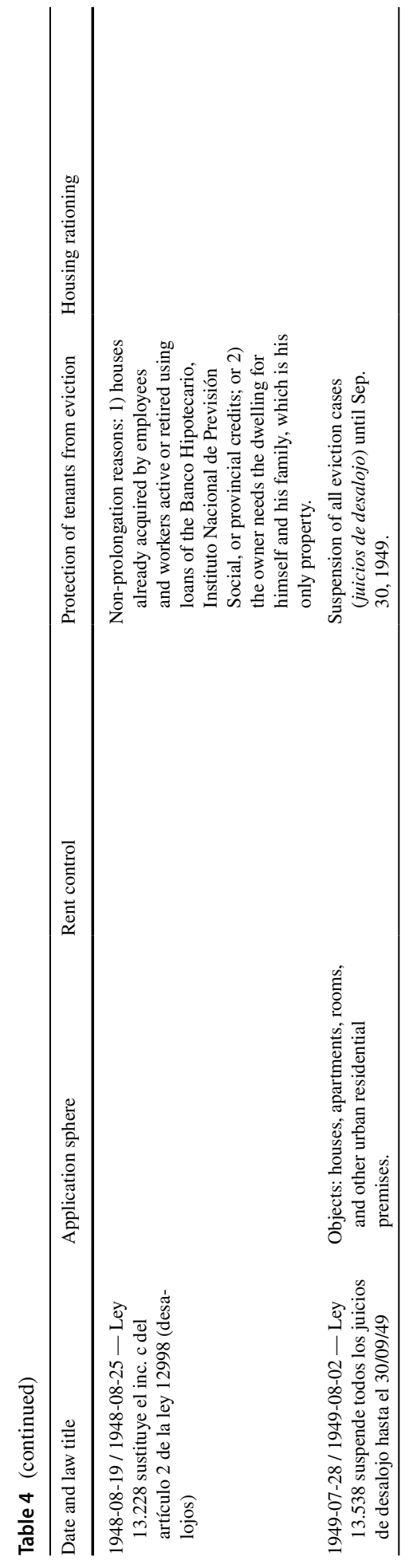




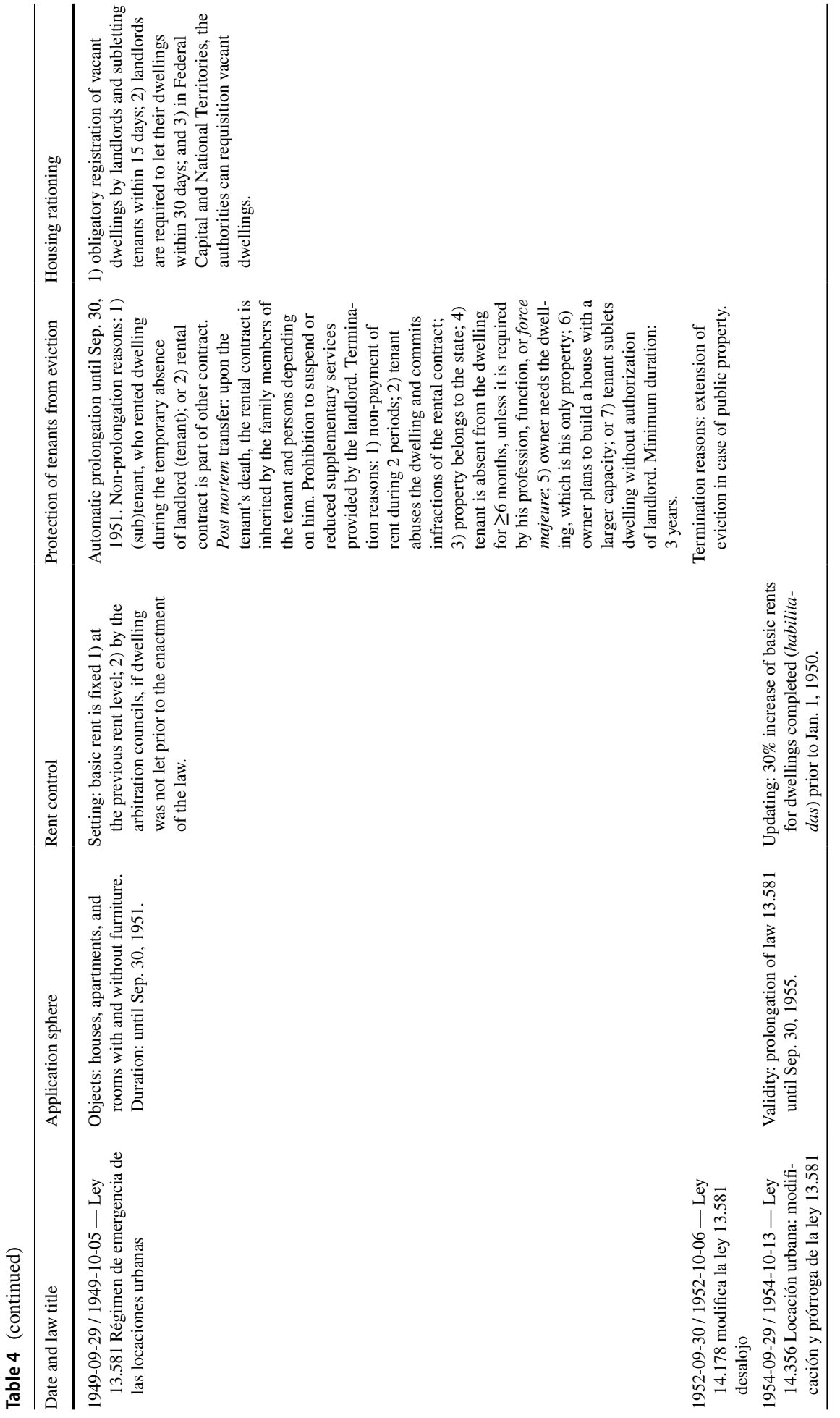




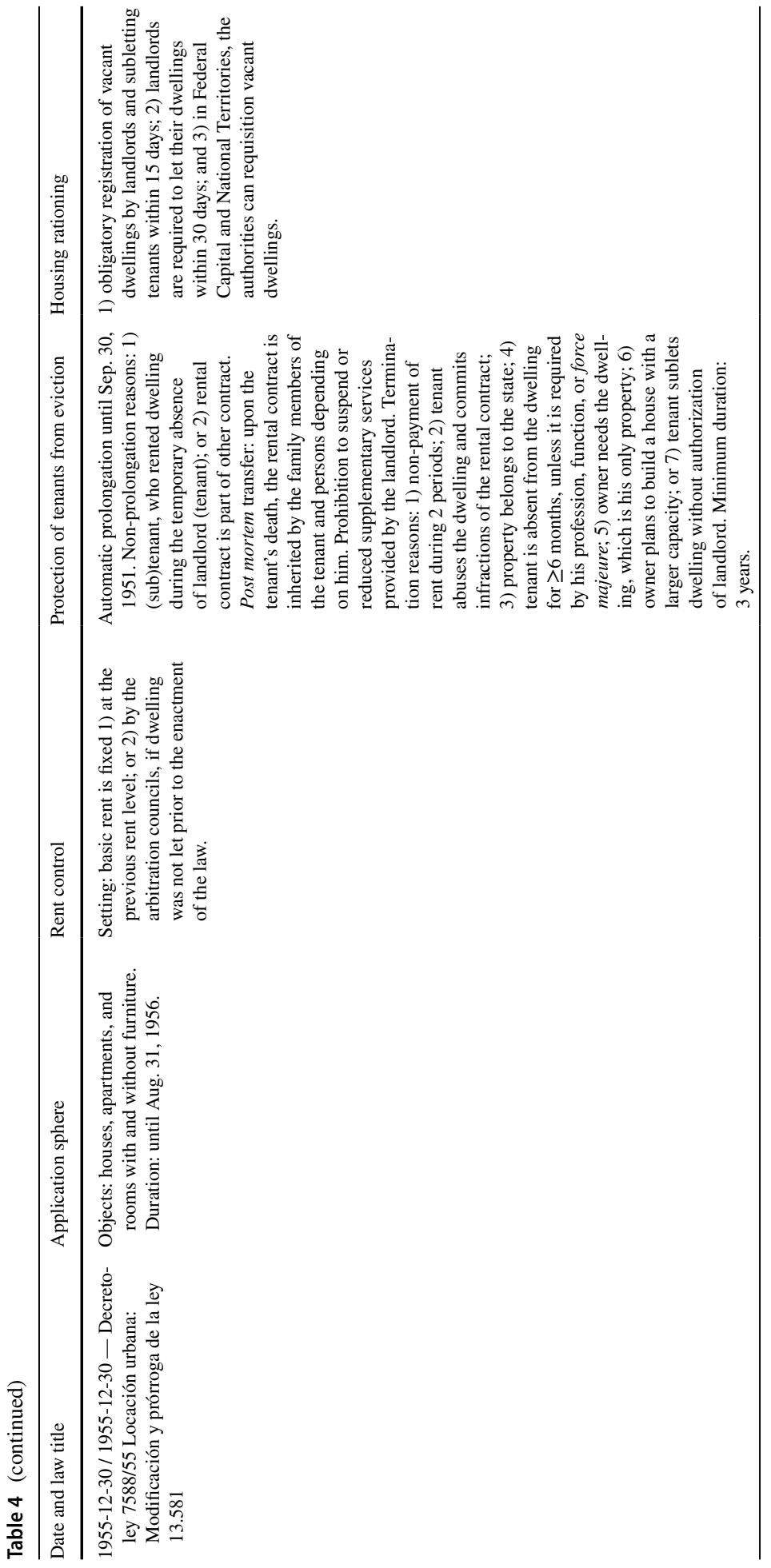




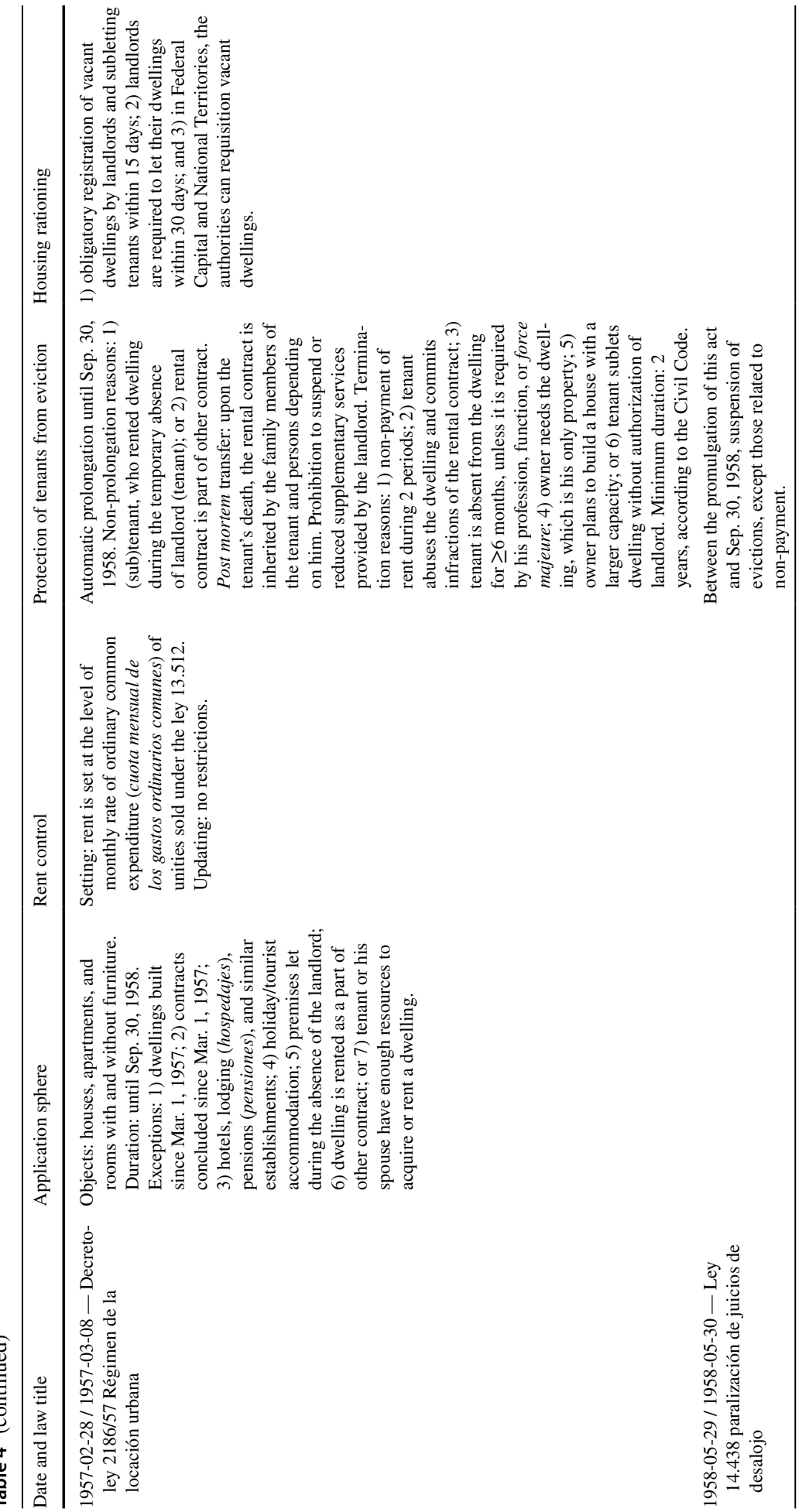




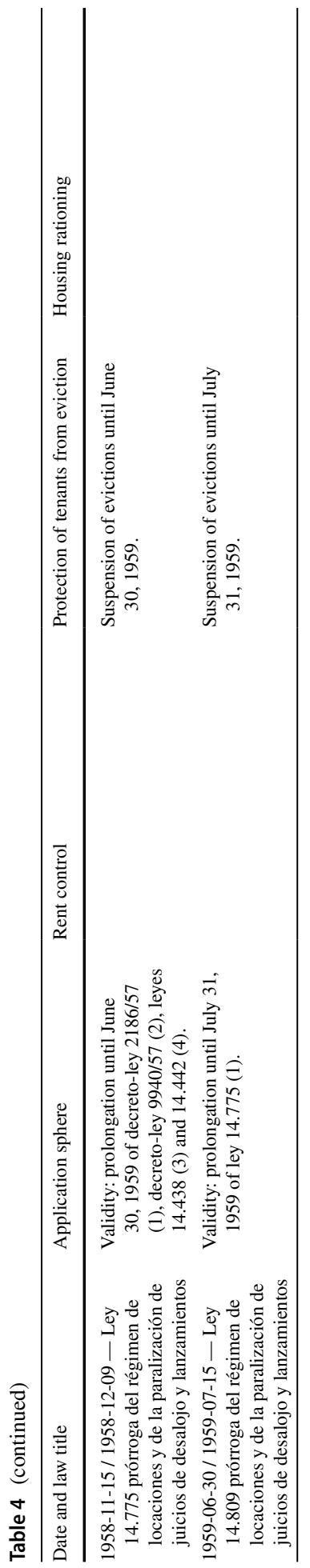




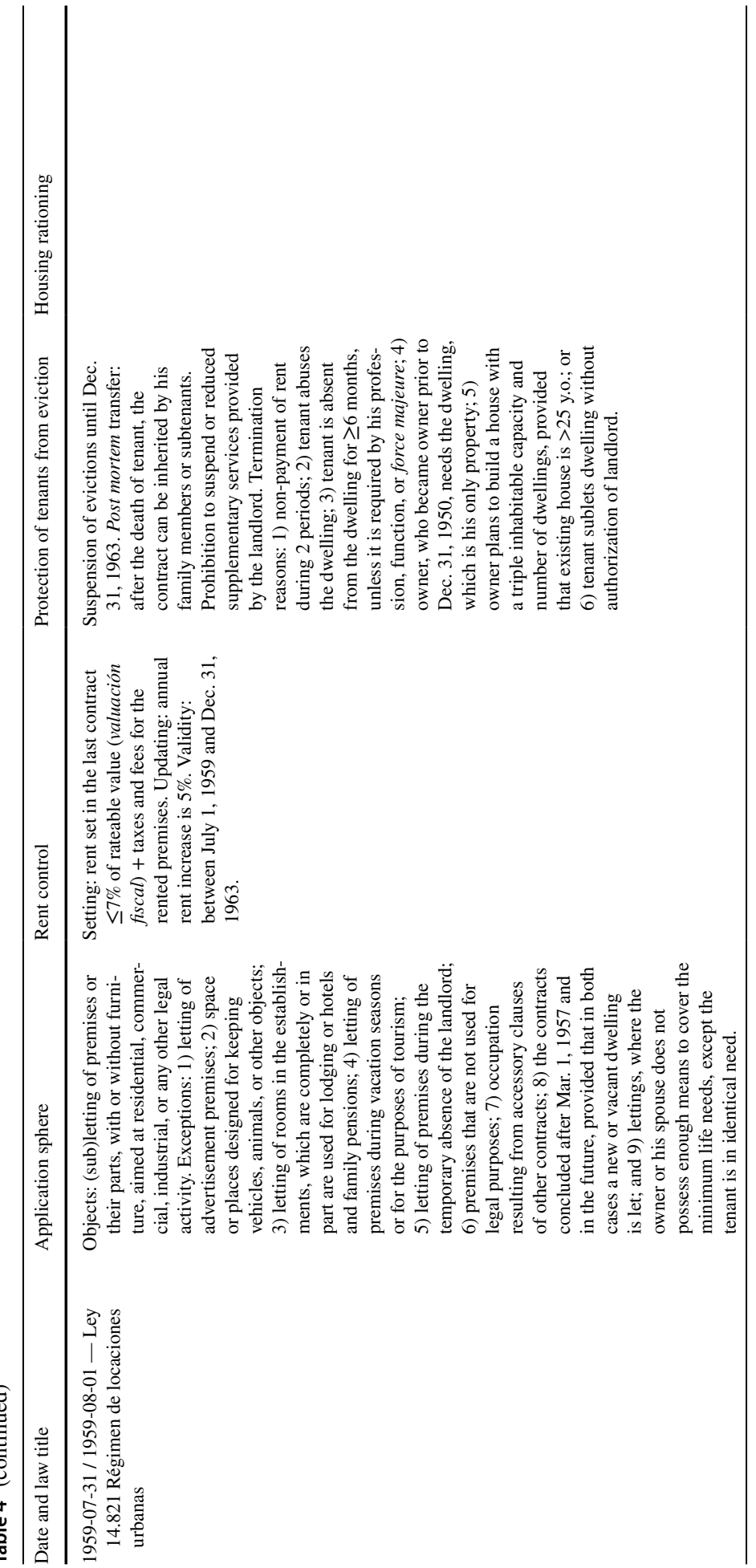




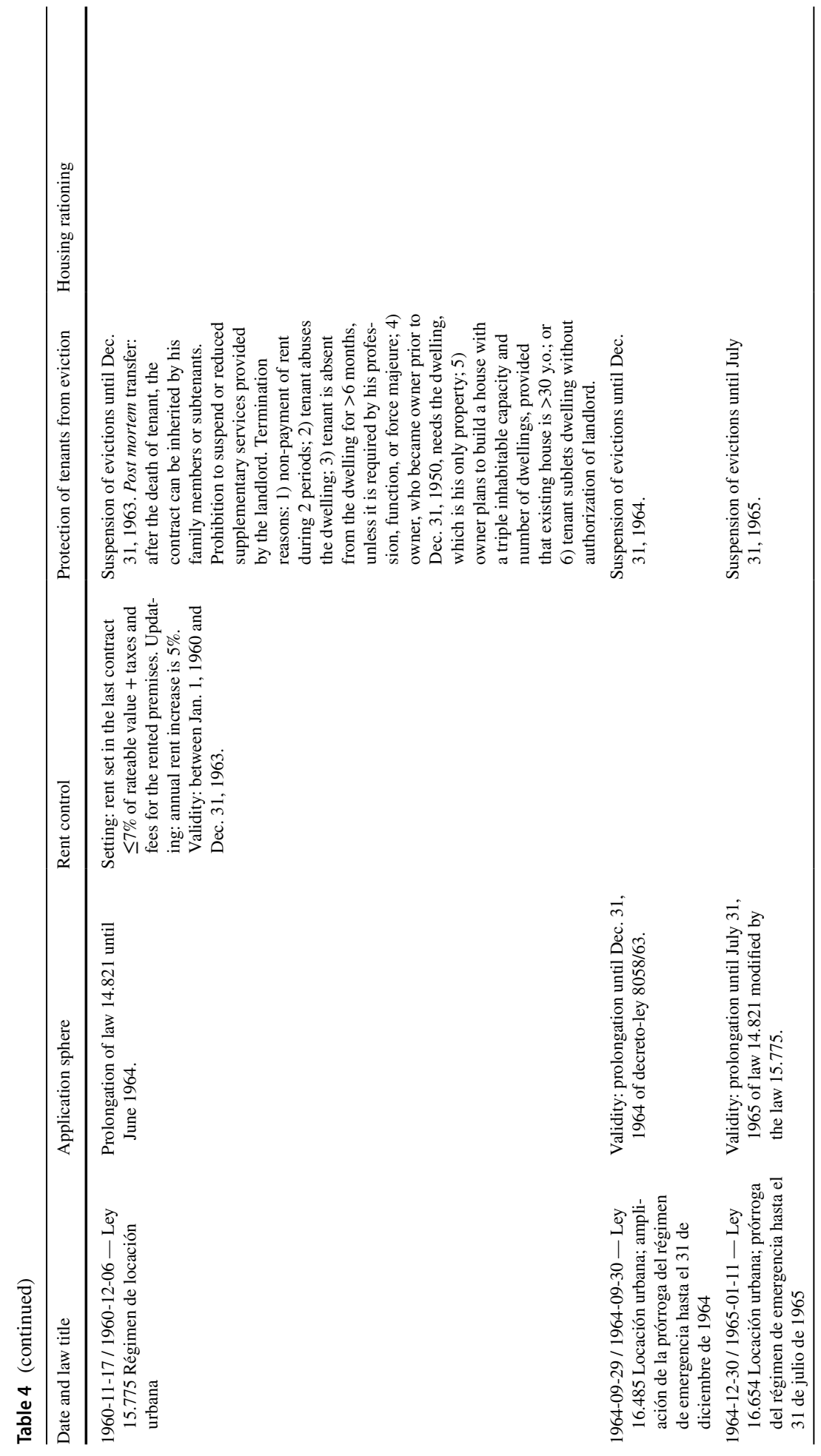




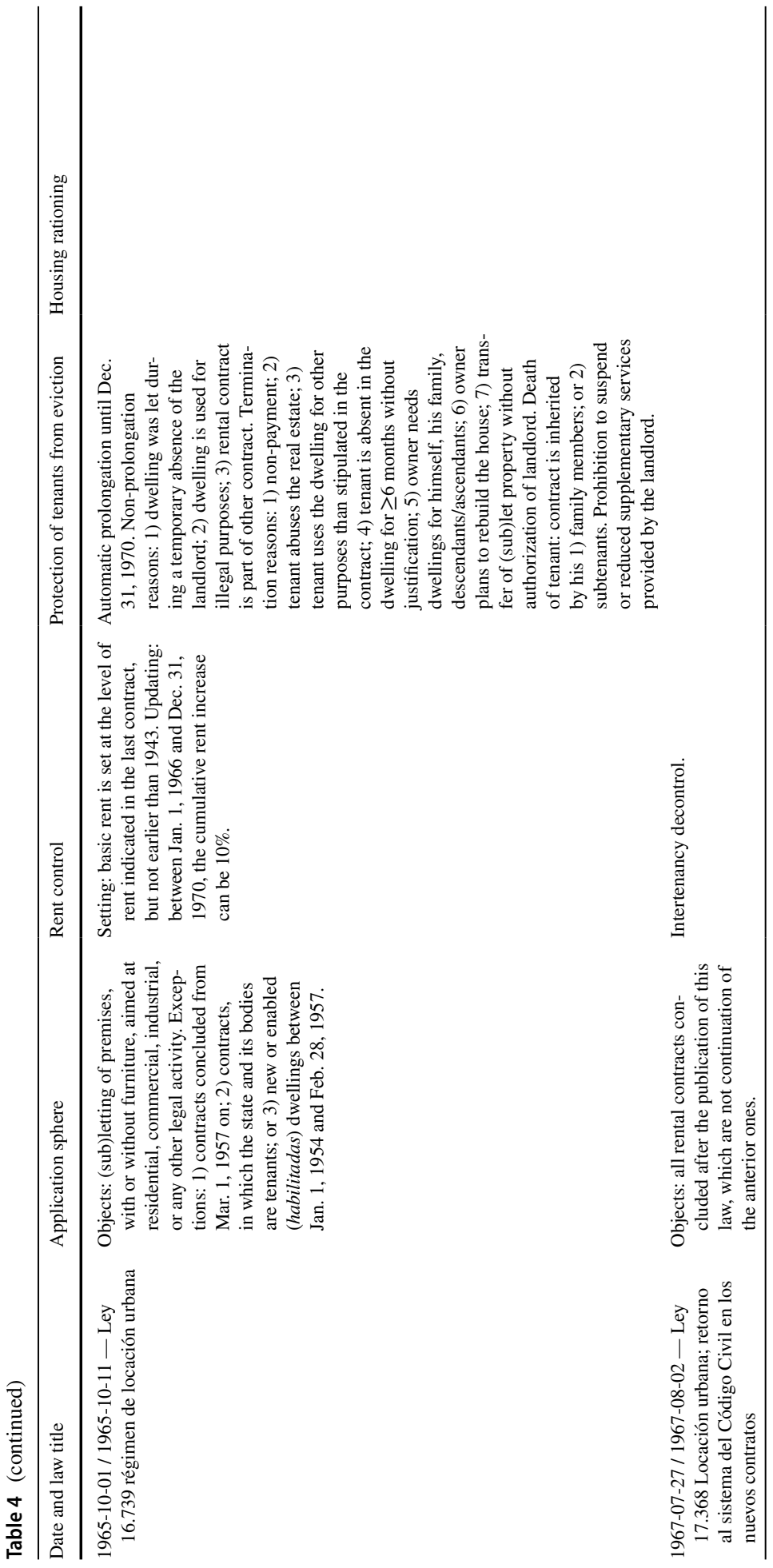




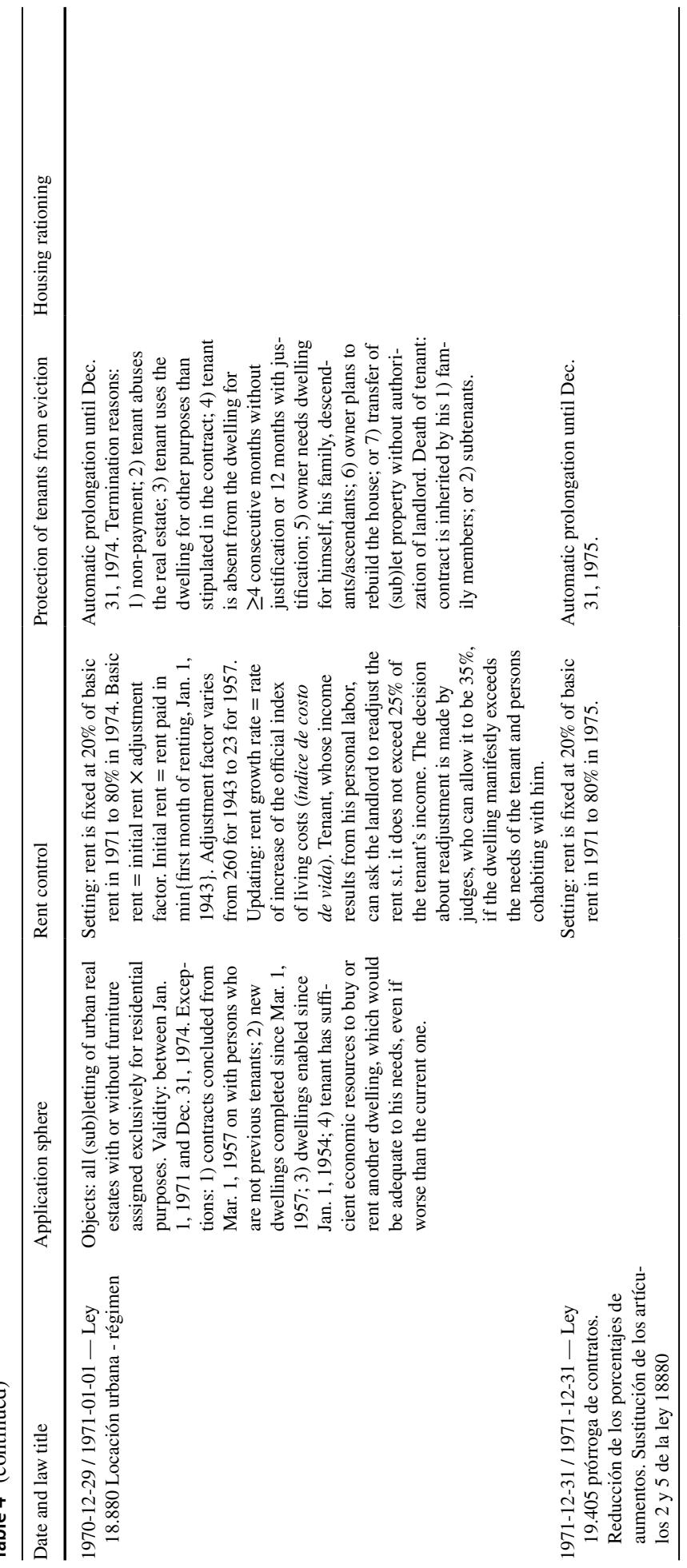




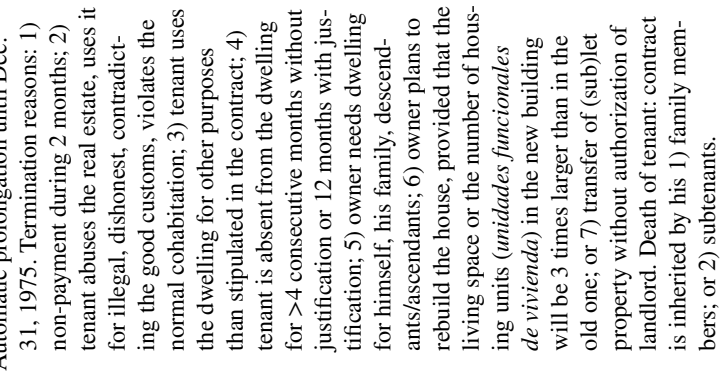

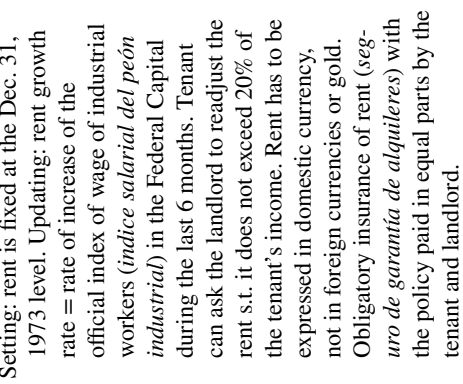

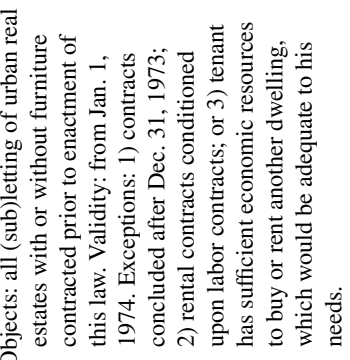

$\frac{1}{80}$

|

공

总

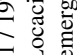

고월

넝

占 穴 


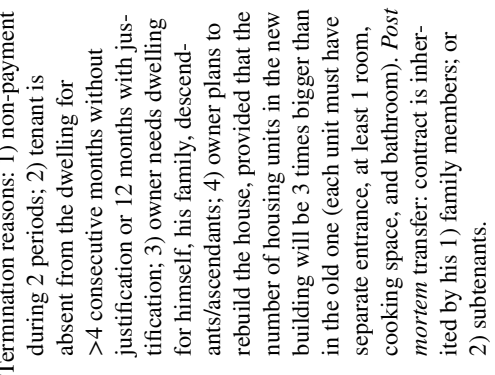

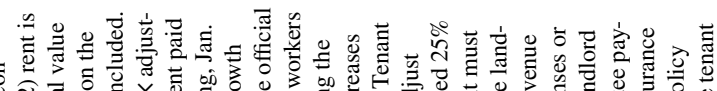

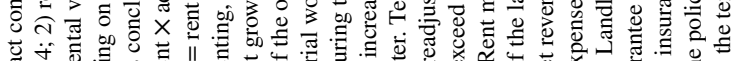

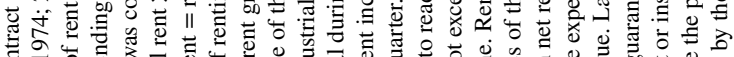

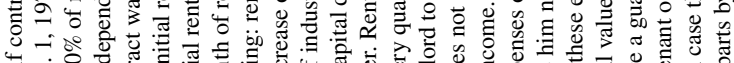

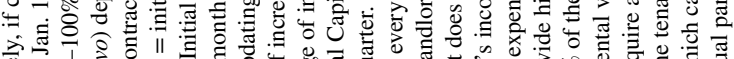

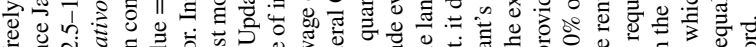

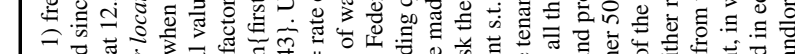

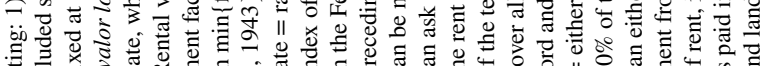

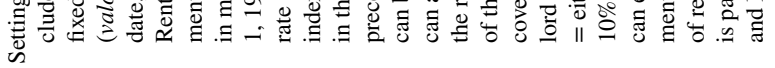

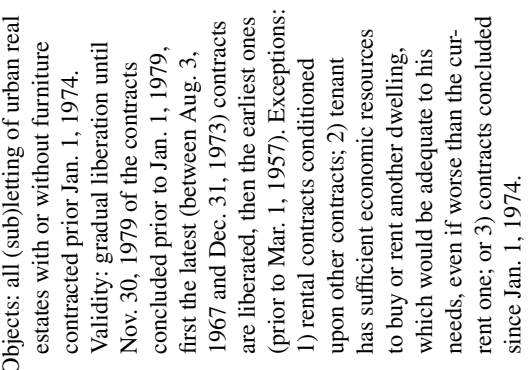

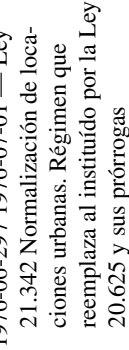



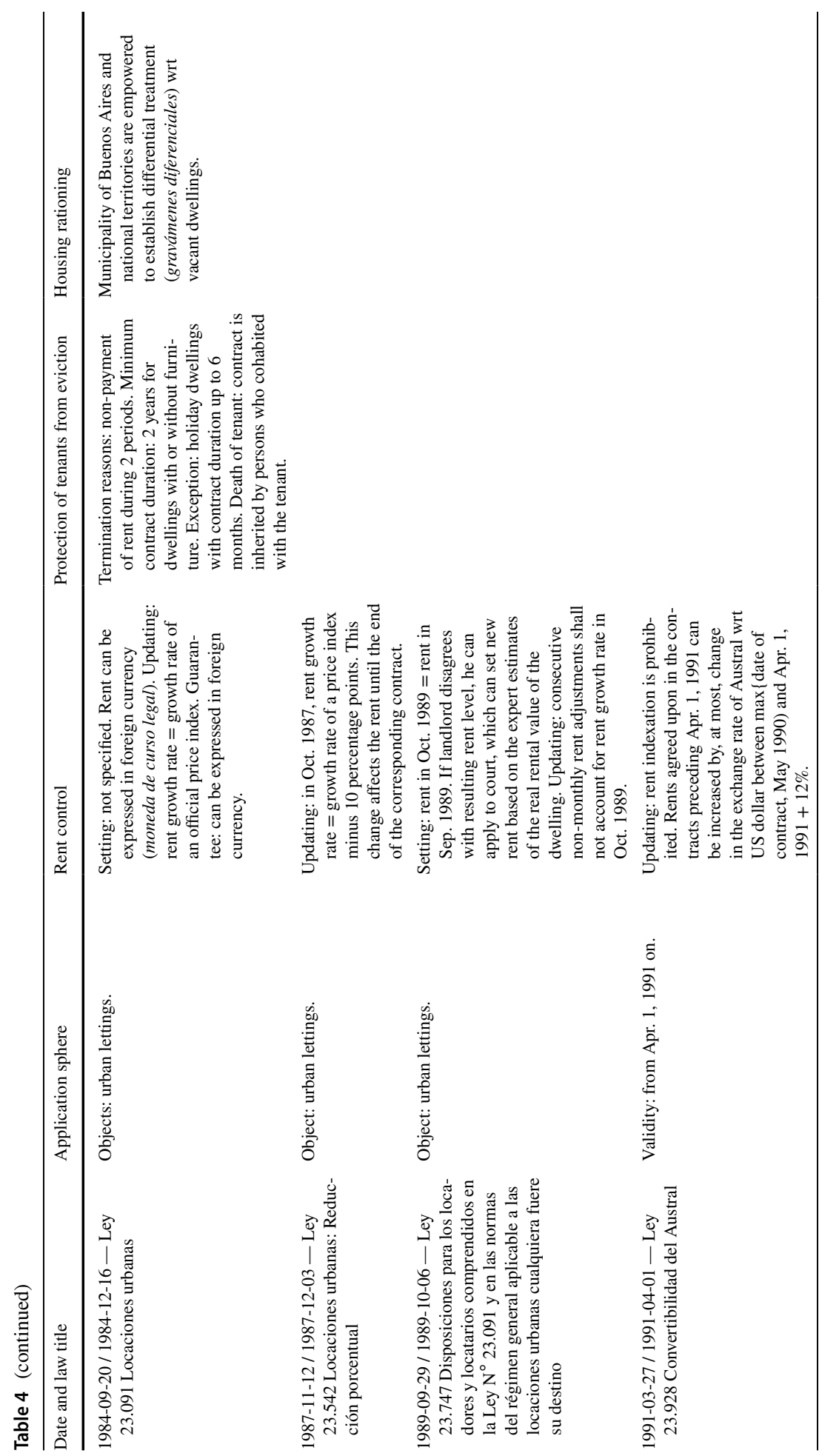


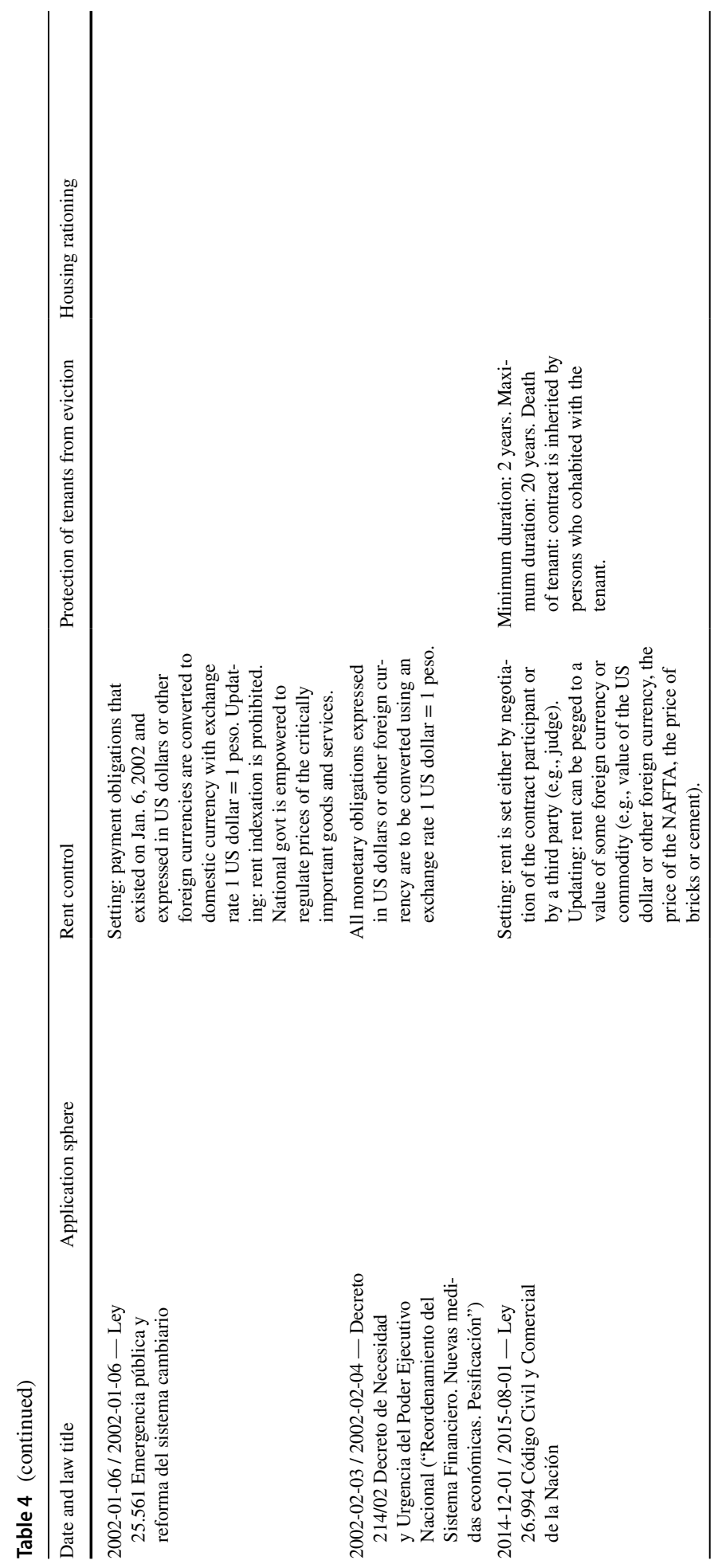




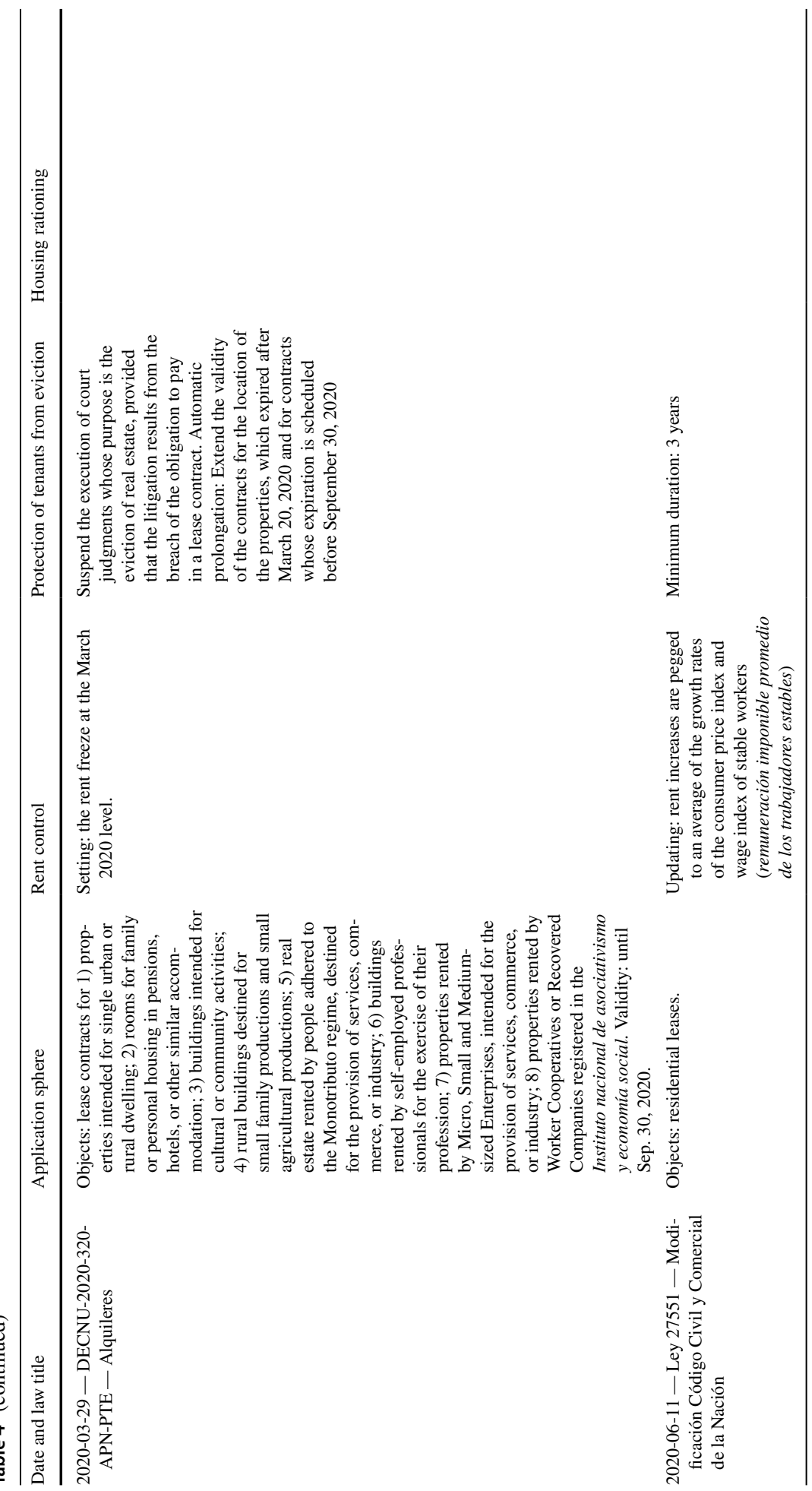


Table 5 Results of augmented Dickey-Fuller stationarity tests

\begin{tabular}{llll}
\hline Variable & No drift no trend & $\begin{array}{l}\text { With drift no } \\
\text { trend }\end{array}$ & $\begin{array}{l}\text { With drift } \\
\text { and trend }\end{array}$ \\
\hline Levels & & & \\
LRRent & 0.237 & 0.691 & 0.775 \\
RIRate & 0.010 & 0.060 & 0.195 \\
LPop & 0.979 & 0.010 & 0.875 \\
Lcgdppc & 0.984 & 0.777 & 0.020 \\
LPermits & 0.087 & 0.798 & 0.010 \\
Differences & & & \\
DLRRent & 0.010 & 0.010 & 0.024 \\
DRIRate & 0.010 & 0.010 & 0.010 \\
DLPop & 0.282 & 0.413 & 0.010 \\
DLcgdppc & 0.010 & 0.010 & 0.010 \\
DLPermits & 0.010 & 0.010 & 0.010 \\
\hline
\end{tabular}


Table 6 Estimation results of OLS and MARS models for real rent growth

\begin{tabular}{|c|c|c|c|c|}
\hline \multirow[t]{2}{*}{ Variable } & \multicolumn{2}{|c|}{ Linear model } & \multicolumn{2}{|l|}{ MARS } \\
\hline & (1) & (2) & (3) & (4) \\
\hline \multirow[t]{2}{*}{ Constant } & 0.089 & 0.270 & $-0.035^{* * *}$ & $-0.020^{* * *}$ \\
\hline & (0.069) & $(0.271)$ & $(0.000)$ & $(0.000)$ \\
\hline \multirow[t]{2}{*}{ DLRRent_L1 } & -0.127 & -0.147 & & \\
\hline & $(0.143)$ & $(0.145)$ & & \\
\hline \multirow[t]{2}{*}{ RIRate_L1 } & $-0.003^{*}$ & $-0.003^{*}$ & $-0.003^{* * *}$ & $-0.003^{* * *}$ \\
\hline & $(0.002)$ & $(0.002)$ & $(0.000)$ & $(0.000)$ \\
\hline \multirow[t]{2}{*}{ DDLPop_L1 } & 12.591 & 13.568 & & \\
\hline & $(20.511)$ & $(21.268)$ & & \\
\hline \multirow[t]{2}{*}{ DLgdppc_L1 } & 0.397 & 0.417 & & \\
\hline & $(0.595)$ & $(0.619)$ & & \\
\hline \multirow[t]{2}{*}{ DLPermits_L1 } & -0.060 & -0.059 & & \\
\hline & $(0.093)$ & $(0.097)$ & & \\
\hline \multirow[t]{2}{*}{ D_meth1 } & -0.019 & -0.085 & & \\
\hline & $(0.084)$ & $(0.121)$ & & \\
\hline \multirow[t]{2}{*}{ D_meth2 } & $-0.142^{* *}$ & $-0.200^{*}$ & & $-0.103^{* * *}$ \\
\hline & $(0.065)$ & $(0.117)$ & & $(0.000)$ \\
\hline \multirow[t]{2}{*}{ D_meth3 } & -0.068 & -0.073 & & \\
\hline & $(0.124)$ & $(0.118)$ & & \\
\hline \multirow[t]{2}{*}{ D_meth4 } & -0.076 & -0.146 & & \\
\hline & $(0.072)$ & $(0.147)$ & & \\
\hline \multirow[t]{2}{*}{$D \_$meth5 } & 0.077 & 0.070 & & \\
\hline & $(0.075)$ & & & \\
\hline D_meth6 & -0.065 & -0.071 & & \\
\hline \multirow[t]{2}{*}{ RMRI_L1 } & -0.172 & & & \\
\hline & $(0.168)$ & & & \\
\hline \multirow[t]{2}{*}{ Rent_laws_L1 } & & 0.028 & & \\
\hline & & $(0.223)$ & & \\
\hline \multirow[t]{2}{*}{ Tenure_security_L1 } & & -0.530 & & \\
\hline & & $(0.703)$ & & \\
\hline \multirow[t]{2}{*}{ Rationing_L1 } & -0.061 & 0.898 & & \\
\hline & $(0.509)$ & $(1.650)$ & & \\
\hline \multirow[t]{2}{*}{ 'h(RMRI_L1-0.541667)' } & & & $-0.464^{* * *}$ & \\
\hline & & & $(0.000)$ & \\
\hline Observations & 90 & 90 & 90 & 90 \\
\hline Adjusted $R^{2}$ & 0.049 & 0.048 & 0.104 & 0.101 \\
\hline
\end{tabular}

${ }^{*} p<0.1 ;{ }^{* *} p<0.05 ;{ }^{* * *} p<0.01$ 
Table 7 Estimation results of OLS model for real rent growth with different lags of regulation indices

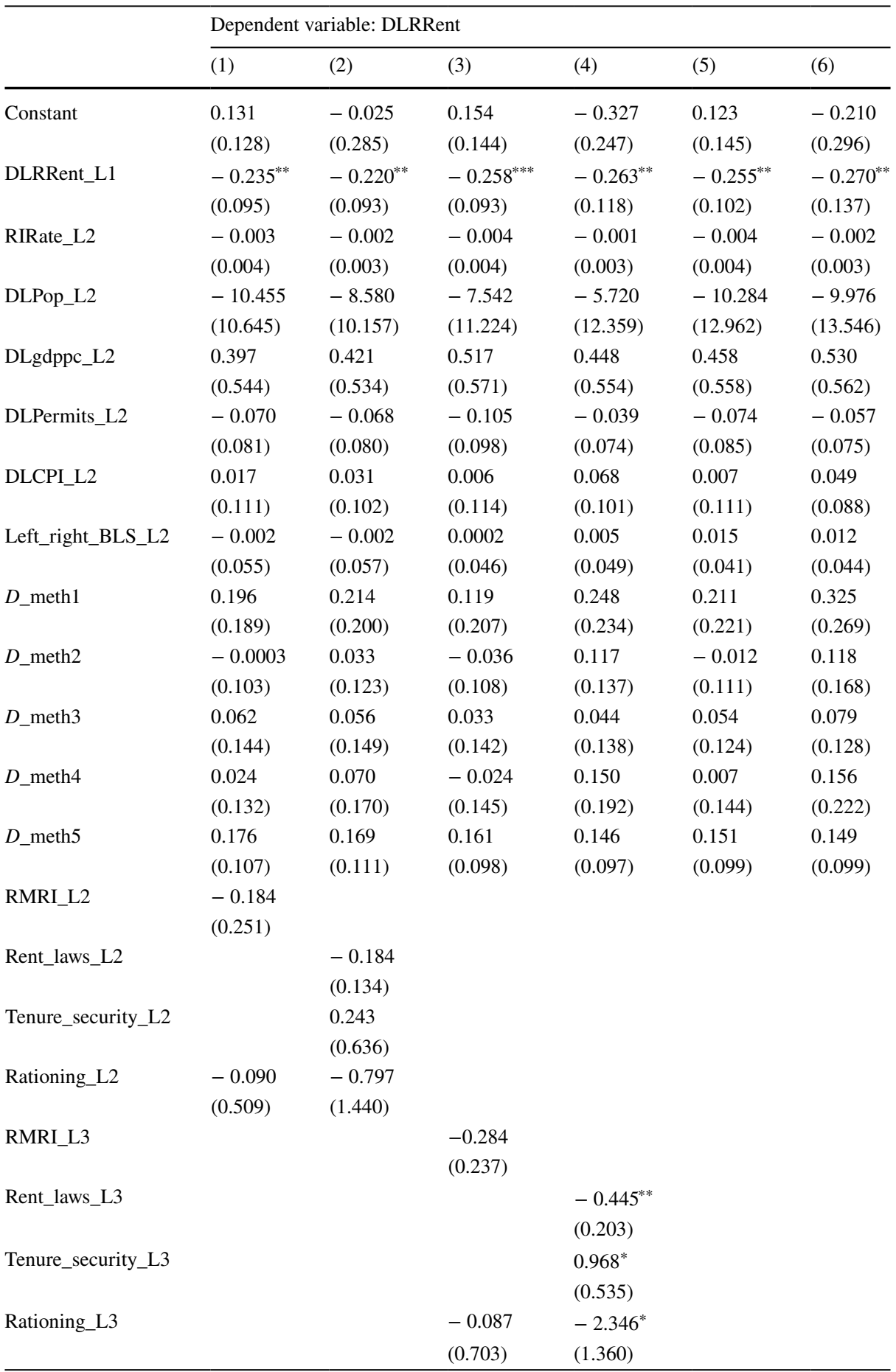


Table 7 (continued)

Dependent variable: DLRRent
(1)
(2)
(3)

(4)

(5)

(6)

RMRI_L4

(0.227)

Rent_laws_L4

$-0.326$

$0.263)$

Tenure_security_L4

0.689

Rationing_L4

(0.705)

$0.012-1.520$

Observations

86

86

86

(0.625)

(1.522)

$R^{2}$

0.193

0.198

0.220

86

86

Adjusted $R^{2}$

0.034

0.026

0.067

0.261

0.193

0.208

${ }^{*} p<0.1 ;{ }^{* *} p<0.05 ;{ }^{* * *} p<0.01$ 
Table 8 Estimation results of OLS model for real rent growth with different proxies for economic growth and demographics

\begin{tabular}{|c|c|c|c|c|c|c|}
\hline & \multicolumn{6}{|c|}{ Dependent variable: DLRRent } \\
\hline & (1) & (2) & (3) & (4) & (5) & (6) \\
\hline Constant & $\begin{array}{l}0.131 \\
(0.128)\end{array}$ & $\begin{array}{l}-0.025 \\
(0.285)\end{array}$ & $\begin{array}{l}0.130 \\
(0.126)\end{array}$ & $\begin{array}{l}-0.030 \\
(0.289)\end{array}$ & $\begin{array}{l}0.036 \\
(0.081)\end{array}$ & $\begin{array}{l}-0.156 \\
(0.256)\end{array}$ \\
\hline DLRRent_L1 & $\begin{array}{l}-0.235^{* *} \\
(0.095)\end{array}$ & $\begin{array}{l}-0.220^{* *} \\
(0.093)\end{array}$ & $\begin{array}{l}-0.237^{* *} \\
(0.095)\end{array}$ & $\begin{array}{l}-0.221^{* *} \\
(0.093)\end{array}$ & $\begin{array}{l}-0.225^{* *} \\
(0.095)\end{array}$ & $\begin{array}{l}-0.203^{* *} \\
(0.088)\end{array}$ \\
\hline RIRate_L2 & $\begin{array}{l}-0.003 \\
(0.004)\end{array}$ & $\begin{array}{l}-0.002 \\
(0.003)\end{array}$ & $\begin{array}{l}-0.003 \\
(0.004)\end{array}$ & $\begin{array}{l}-0.002 \\
(0.003)\end{array}$ & $\begin{array}{l}-0.003 \\
(0.003)\end{array}$ & $\begin{array}{l}-0.002 \\
(0.003)\end{array}$ \\
\hline DLPop_L2 & $\begin{array}{l}-10.455 \\
(10.645)\end{array}$ & $\begin{array}{l}-8.580 \\
(10.157)\end{array}$ & $\begin{array}{l}-10.887 \\
(10.579)\end{array}$ & $\begin{array}{l}-8.983 \\
(10.063)\end{array}$ & & \\
\hline DLgdppc_L2 & $\begin{array}{l}0.397 \\
(0.544)\end{array}$ & $\begin{array}{l}0.421 \\
(0.534)\end{array}$ & & & & \\
\hline DLMarriage_CF_L2 & & & & & $\begin{array}{l}0.437 \\
(0.338)\end{array}$ & $\begin{array}{l}0.467 \\
(0.319)\end{array}$ \\
\hline DLRGDP_own_L2 & & & $\begin{array}{l}0.468 \\
(0.540)\end{array}$ & $\begin{array}{l}0.498 \\
(0.532)\end{array}$ & $\begin{array}{l}0.368 \\
(0.502)\end{array}$ & $\begin{array}{l}0.408 \\
(0.486)\end{array}$ \\
\hline DLPermits_L2 & $\begin{array}{l}-0.070 \\
(0.081)\end{array}$ & $\begin{array}{l}-0.068 \\
(0.080)\end{array}$ & $\begin{array}{l}-0.075 \\
(0.081)\end{array}$ & $\begin{array}{l}-0.074 \\
(0.080)\end{array}$ & $\begin{array}{l}-0.063 \\
(0.077)\end{array}$ & $\begin{array}{l}-0.060 \\
(0.076)\end{array}$ \\
\hline DLCPI_L2 & $\begin{array}{l}0.017 \\
(0.111)\end{array}$ & $\begin{array}{l}0.031 \\
(0.102)\end{array}$ & $\begin{array}{l}0.021 \\
(0.109)\end{array}$ & $\begin{array}{l}0.037 \\
(0.100)\end{array}$ & $\begin{array}{l}0.013 \\
(0.107)\end{array}$ & $\begin{array}{l}0.032 \\
(0.098)\end{array}$ \\
\hline Left_right_BLS_L2 & $\begin{array}{l}-0.002 \\
(0.055)\end{array}$ & $\begin{array}{l}-0.002 \\
(0.057)\end{array}$ & $\begin{array}{l}-0.001 \\
(0.055)\end{array}$ & $\begin{array}{l}-0.001 \\
(0.057)\end{array}$ & $\begin{array}{l}0.010 \\
(0.053)\end{array}$ & $\begin{array}{l}0.011 \\
(0.055)\end{array}$ \\
\hline D_meth1 & $\begin{array}{l}0.196 \\
(0.189)\end{array}$ & $\begin{array}{l}0.214 \\
(0.200)\end{array}$ & $\begin{array}{l}0.197 \\
(0.190)\end{array}$ & $\begin{array}{l}0.215 \\
(0.201)\end{array}$ & $\begin{array}{l}0.018 \\
(0.057)\end{array}$ & $\begin{array}{l}0.084 \\
(0.103)\end{array}$ \\
\hline D_meth2 & $\begin{array}{l}-0.0003 \\
(0.103)\end{array}$ & $\begin{array}{l}0.033 \\
(0.123)\end{array}$ & $\begin{array}{l}-0.002 \\
(0.103)\end{array}$ & $\begin{array}{l}0.032 \\
(0.124)\end{array}$ & $\begin{array}{l}-0.106 \\
(0.080)\end{array}$ & $\begin{array}{l}-0.042 \\
(0.104)\end{array}$ \\
\hline D_meth3 & $\begin{array}{l}0.062 \\
(0.144)\end{array}$ & $\begin{array}{l}0.056 \\
(0.149)\end{array}$ & $\begin{array}{l}0.061 \\
(0.143)\end{array}$ & $\begin{array}{l}0.055 \\
(0.148)\end{array}$ & $\begin{array}{l}-0.018 \\
(0.151)\end{array}$ & $\begin{array}{l}-0.013 \\
(0.151)\end{array}$ \\
\hline D_meth4 & $\begin{array}{l}0.024 \\
(0.132)\end{array}$ & $\begin{array}{l}0.070 \\
(0.170)\end{array}$ & $\begin{array}{l}0.019 \\
(0.132)\end{array}$ & $\begin{array}{l}0.066 \\
(0.170)\end{array}$ & $\begin{array}{l}-0.047 \\
(0.096)\end{array}$ & $\begin{array}{l}0.031 \\
(0.151)\end{array}$ \\
\hline D_meth5 & $\begin{array}{l}0.176 \\
(0.107)\end{array}$ & $\begin{array}{l}0.169 \\
(0.111)\end{array}$ & $\begin{array}{l}0.172 \\
(0.106)\end{array}$ & $\begin{array}{l}0.166 \\
(0.110)\end{array}$ & $\begin{array}{l}0.119 \\
(0.096)\end{array}$ & $\begin{array}{l}0.116 \\
(0.101)\end{array}$ \\
\hline RMRI_L2 & $\begin{array}{l}-0.184 \\
(0.251)\end{array}$ & & $\begin{array}{l}-0.184 \\
(0.251)\end{array}$ & & $\begin{array}{l}-0.186 \\
(0.239)\end{array}$ & \\
\hline Rent_laws_L2 & & $\begin{array}{l}-0.184 \\
(0.134)\end{array}$ & & $\begin{array}{l}-0.187 \\
(0.136)\end{array}$ & & $\begin{array}{l}-0.212 \\
(0.146)\end{array}$ \\
\hline Tenure_security_L2 & & $\begin{array}{l}0.243 \\
(0.636)\end{array}$ & & $\begin{array}{l}0.253 \\
(0.643)\end{array}$ & & $\begin{array}{l}0.369 \\
(0.607)\end{array}$ \\
\hline Rationing_L2 & $\begin{array}{l}-0.090 \\
(0.509)\end{array}$ & $\begin{array}{l}-0.797 \\
(1.440)\end{array}$ & $\begin{array}{l}-0.084 \\
(0.510)\end{array}$ & $\begin{array}{l}-0.812 \\
(1.452)\end{array}$ & $\begin{array}{l}-0.083 \\
(0.521)\end{array}$ & $\begin{array}{l}-1.043 \\
(1.398)\end{array}$ \\
\hline Observations & 86 & 86 & 86 & 86 & 86 & 86 \\
\hline$R^{2}$ & 0.193 & 0.198 & 0.195 & 0.200 & 0.202 & 0.211 \\
\hline Adjusted $R^{2}$ & 0.034 & 0.026 & 0.037 & 0.029 & 0.045 & 0.041 \\
\hline
\end{tabular}

${ }^{*} p<0.1 ;{ }^{* *} p<0.05 ;{ }^{* * *} p<0.01$ 
Fig. 1 Tenant rate in Argentina, 1947-2018. Note: The tenant rate is measured as a percentage share of tenant households in the total number of households. Source: Benítez (2016), Cosacov (2012), Reese et al. (2014). (Color figure online)

Fig. 2 Various housing rental price indices, 1914-2017. Note: The numbers in the legend denote the basis years of the corresponding indices. CABA stands for Ciudad Autónoma de Buenos Aires. The vertical axis uses a logarithmic scale in order to make the low index values visible. (Color figure online)
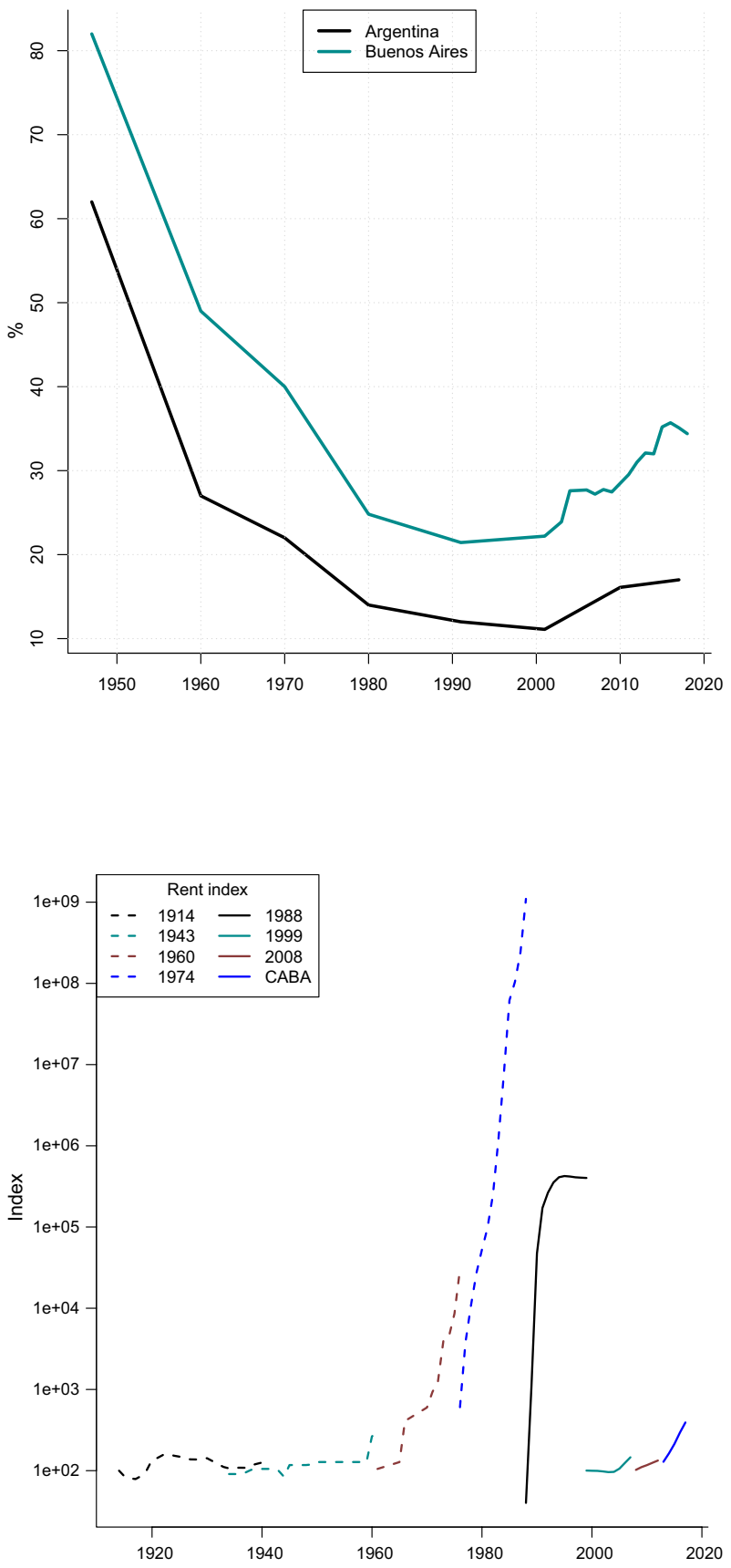

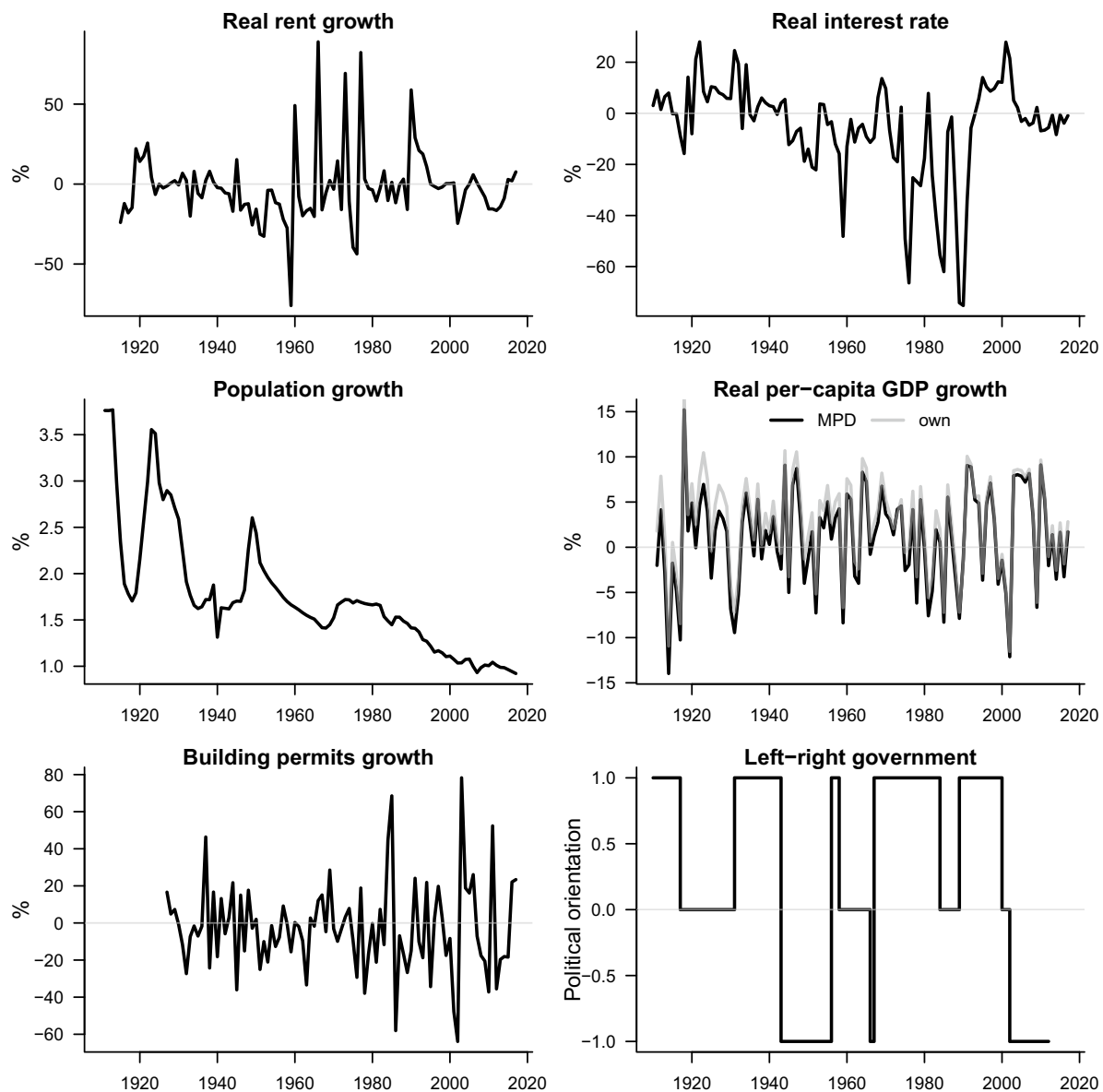

Fig. 3 Dependent and control variables, 1910-2017. Note: The growth rates are computed as the percentage annual changes. The real values are obtained by dividing the nominal values by the consumer price index 

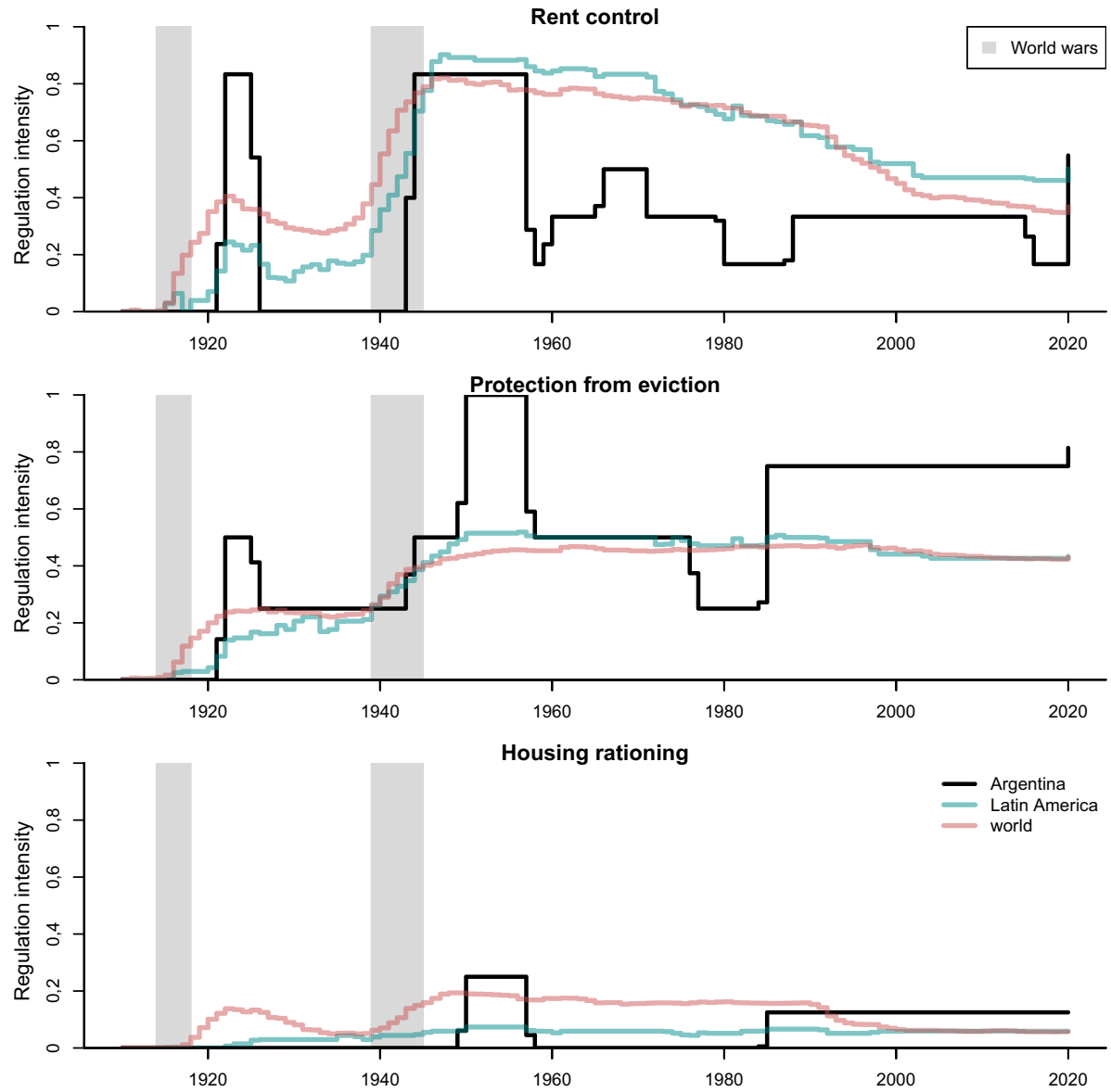

Fig. 4 Rental market regulation indices in Argentina, 1910-2020. Note: The lines reflect the intensity of the restrictive rental housing market regulations (rent control, protection of tenants from eviction, and housing rationing) in Argentina (black line), Latin America and Caribbean (green line), and the world as approximated by the 133 countries and states (red line). The higher the index value the more intense the governmental intervention in the rental housing market. Two gray bars correspond to both world wars. (Color figure online) 
Fig. 5 Regulation effects on real rent growth. Note: The figure depicts the estimated effects of rental market regulations on the real rent growth. The intensity displayed on the horizontal axis varies from 0 (no regulations) to 1 (very strict regulations)

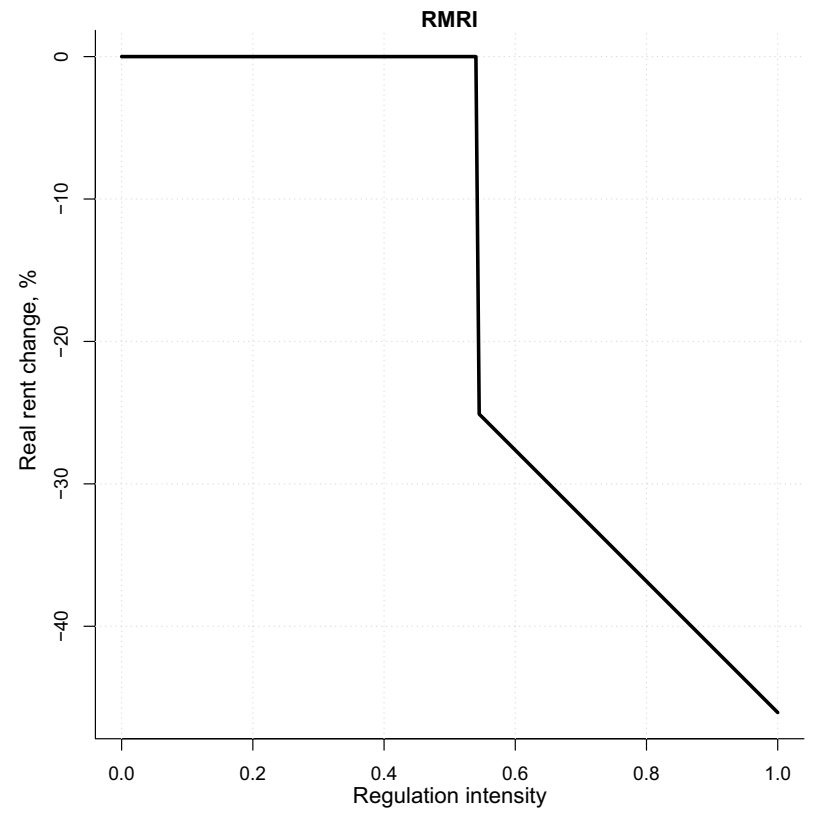



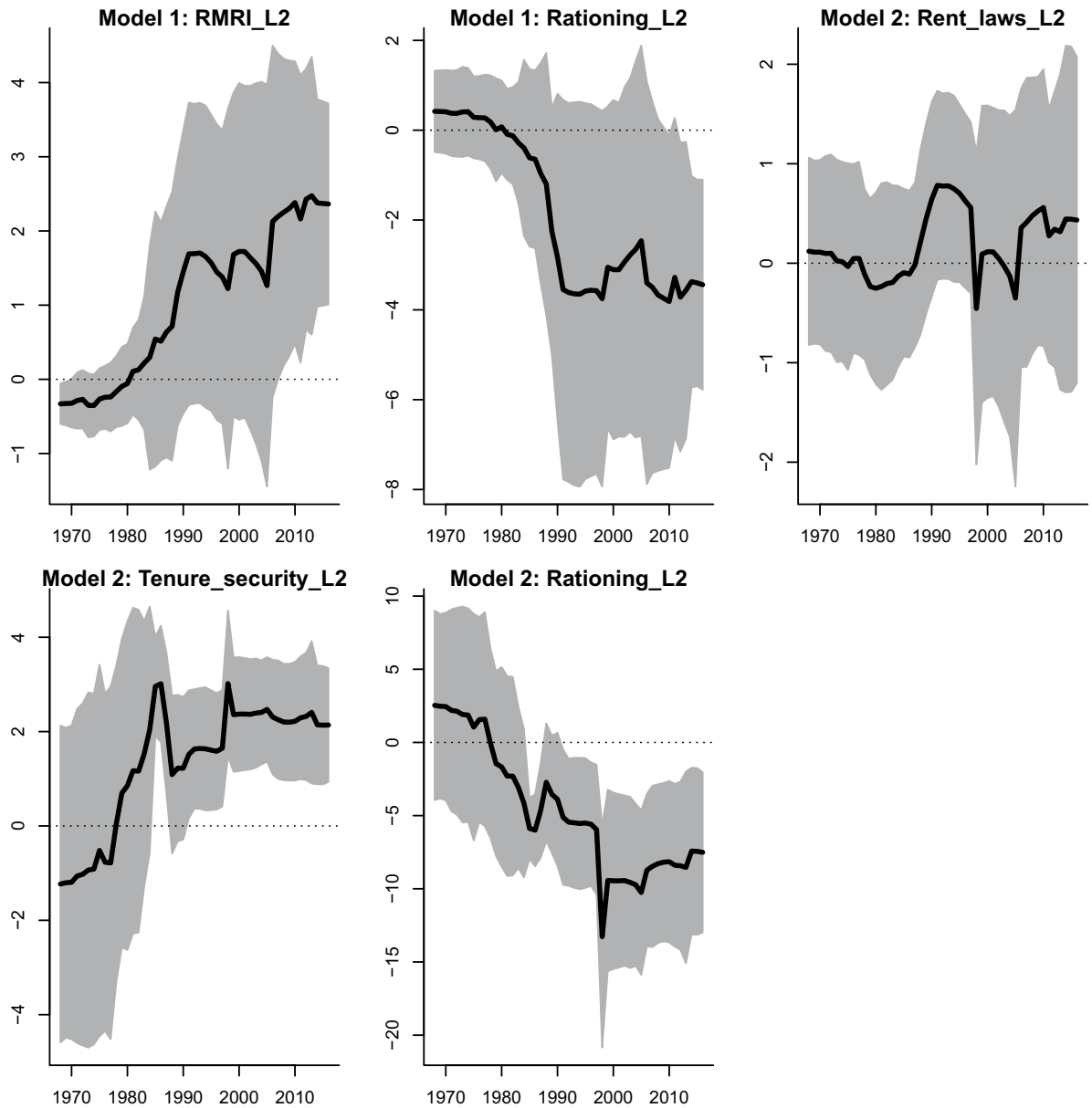

Fig. 6 Coefficients of regulation indices estimated using rolling windows. Note: The regression coefficients displayed as a black line are estimated using a rolling 40-year window. The horizontal axis shows the last year of each 40-year period. For example, the estimate shown for 1980 was estimated using the period 1941-1980. The gray shaded areas show the $95 \%$-confidence intervals, while dotted line corresponds to 0

Funding Open Access funding enabled and organized by Projekt DEAL.

Open Access This article is licensed under a Creative Commons Attribution 4.0 International License, which permits use, sharing, adaptation, distribution and reproduction in any medium or format, as long as you give appropriate credit to the original author(s) and the source, provide a link to the Creative Commons licence, and indicate if changes were made. The images or other third party material in this article are included in the article's Creative Commons licence, unless indicated otherwise in a credit line to the material. If material is not included in the article's Creative Commons licence and your intended use is not permitted by statutory regulation or exceeds the permitted use, you will need to obtain permission directly from the copyright holder. To view a copy of this licence, visit http://creativecommons.org/licenses/by/4.0/. 


\section{References}

Arnott, R. (1995). Time for revisionism on rent control? Journal of Economic Perspectives, 9(1), 99-120.

Astorga González, A. (1995). La ciudad como conjunto de viviendas: la función residencial. Espacio, Tiempo y Forma V, I(8), 101-118.

Ault, R. W., Jackson, J. D., \& Saba, R. P. (1994). The effect of long-term rent control on tenant mobility. Journal of Urban Economics, 35(2), 140-158.

Autor, D. H., Palmer, C. J., \& Pathak, P. A. (2014). Housing market spillovers: Evidence from the end of rent control in Cambridge, Massachusetts. Journal of Political Economy, 122(3), 661-717.

Benítez, J. (2016). Buscar un techo. La problemática de los inquilinos y los alquileres en la Ciudad Autónoma de Buenos Aires. Colección es nuestra la ciudad, 2, 5-8.

Bettendorf, L., \& Buyst, E. (1997). Rent control and virtual prices: A case study for interwar Belgium. The Journal of Economic History, 57(3), 654-673.

Blanco, A., Fretes, V., \& Muñoz, A. (2014). Se busca vivienda en alquiler: opciones de política para América Latina y el Caribe. Inter-American Development Bank.

Brambor, T., Lindvall, J., \& Stjernquist, A. (2017). The ideology of heads of government, 1870-2012. version 1.5. Department of Political Science, Lund University. https://heads-of-government.github.io.

Carné, M. A. (2021). El alquiler como régimen de tenencia de la vivienda: características de los hogares inquilinos del Aglomerado Gran Santa Fe entre el tercer trimestre de 2016 y el tercer trimestre de 2019. Revista del Área de Estudios Urbanos, 16(15), 234-252.

Cavallo, A., \& Bertolotto, M. (2016). Serie completa de inflación de Argentina desde 1943 a 2016 (Filling the gap in Argentina's inflation data).

Cosacov, N. (2012). Alquileres e inquilinos en la Ciudad de Buenos Aires. Una radiografía. Buenos Aires: Laboratorio de Políticas Públicas.

Diamond, R., McQuade, T., \& Qian, F. (2019). The effects of rent control expansion on tenants, landlords, and inequality: Evidence from San Francisco. American Economic Review, 109(9), 3365-94.

Downs, A. (1957). An economic theory of democracy. New York: Harper.

Early, D. W., \& Olsen, E. O. (1998). Rent control and homelessness. Regional Science and Urban Economics, 28(6), 797-816.

Engle, R. F., \& Granger, C. W. (1987). Co-integration and error correction: representation, estimation, and testing. Econometrica: Journal of the Econometric Society, 55(2), 251-276.

Ferreres, O. J., et al. (2005). Dos siglos de economía argentina (1810-2004): historia argentina en cifras. Fundación Norte y Sur.

Friedman, J. H. (1991). Multivariate adaptive regression splines. The Annals of Statistics, 19(1), 1-67.

Gerchunoff, P., \& Díaz Alejandro, C. (1989). Peronist economic policies, 1946-55. In G. di Tella \& R. Dornbusch (Eds.), The Political Economy of Argentina, 1946-83. St Antony's/Macmillan Series. (pp. 59-88). London: Palgrave Macmillan.

Glaeser, E. L., \& Luttmer, E. F. (2003). The misallocation of housing under rent control. The American Economic Review, 93(4), 1027-1046.

Grimes, P. W., \& Chressanthis, G. A. (1997). Assessing the effect of rent control on homelessness. Journal of Urban Economics, 41(1), 23-37.

Jenkins, B. (2009). Rent control: Do economists agree? Econ Journal Watch, 6(1), 73-112.

Kholodilin, K. A. (2020a). Housing policy during COVID-19 crisis: Challenges and solutions. DIW focus 2. https://rpubs.com/Konstantin_Xo/COVID19_housing_policies.

Kholodilin, K. A. (2020). Long-term, multicountry perspective on rental market regulations. Housing Policy Debate, 30(6), 994-1015.

Kholodilin, K. A., \& Kohl, S. (2021). Social policy or crowding-out? Tenant protection in comparative long-run perspective. Housing Studies, pp. 1-24. https://www.tandfonline.com/doi/full/10.1080/02673 037.2021 .1900796$.

Krol, R., \& Svorny, S. (2005). The effect of rent control on commute times. Journal of Urban Economics, 58(3), 421-436.

Lucas, R. (1983). Econometric policy evaluation: A critique. In K. Brunner and A. Meltzer (Eds.), Theory, Policy, Institutions: Papers from the Carnegie-Rochester Conferences on Public Policy, pp. 19-46.

Moon, C.-G., \& Stotsky, J. G. (1993). The effect of rent control on housing quality change: A longitudinal analysis. Journal of Political Economy, 101(6), 1114-1148.

Munch, J. R., \& Svarer, M. (2002). Rent control and tenancy duration. Journal of Urban Economics, 52(3), $542-560$.

Olsen, E. O. (1972). An econometric analysis of rent control. Journal of Political Economy, 80(6), 1081-1100. 
Pareja-Eastaway, M., \& Sánchez-Martínez, M. T. (2011). El alquiler: una asignatura pendiente de la política de vivienda en España. Ciudad y Territorio. Estudios Territoriales, 43(167), 53-70.

Reese, E., Almansi, F., Del Valle, J., \& Andrés, J. (2014). Políticas habitacionales y la regulación del alquiler en Argentina. In A. G. Blanco, V. Fretes Cibils, and A. F. Muñoz (Eds.), Busco casa en arriendo: promover el alquiler tiene sentido, Chapter 4, pp. 93-132. Banco Interamericano de Desarrollo.

Sims, D. P. (2007). Out of control: What can we learn from the end of Massachusetts rent control? Journal of Urban Economics, 61(1), 129-151.

Skak, M., \& Bloze, G. (2013). Rent control and misallocation. Urban Studies, 50(10), 1988-2005.

Svarer, M., Rosholm, M., \& Munch, J. R. (2005). Rent control and unemployment duration. Journal of Public Economics, 89(11-12), 2165-2181.

Weber, J. P. (2017). The regulation of private tenancies - a multi-country analysis. PhD Dissertation, Universität Regensburg. Available at https://epub.uni-regensburg.de/36228/1/Weber\%20\%282017\%29_ The $\% 20$ Regulation\%20of\%20Private\%20Tenancies\%20A\%20Multi-Country\%20Analysis.pdf.

Wilhelmsson, M., Andersson, R., \& Klingborg, K. (2011). Rent control and vacancies in Sweden. International Journal of Housing Markets and Analysis, 4(2), 105-129.

Publisher's Note Springer Nature remains neutral with regard to jurisdictional claims in published maps and institutional affiliations. 